\title{
Implementation of a chemical background method for atmospheric OH measurements by laser-induced fluorescence: characterisation and observations from the UK and China
}

\author{
Robert Woodward-Massey ${ }^{1, a}$, Eloise J. Slater ${ }^{1}$, Jake Alen ${ }^{1}$, Trevor Ingham ${ }^{1,2}$, Danny R. Cryer ${ }^{1}$, \\ Leanne M. Stimpson ${ }^{1}$, Chunxiang Ye ${ }^{1, a}$, Paul W. Seakins ${ }^{1}$, Lisa K. Whalley ${ }^{1,2}$, and Dwayne E. Heard ${ }^{1}$ \\ ${ }^{1}$ School of Chemistry, University of Leeds, Leeds, LS2 9JT, UK \\ ${ }^{2}$ National Centre for Atmospheric Science, University of Leeds, Leeds, LS2 9JT, UK \\ ${ }^{a}$ now at: College of Environmental Sciences and Engineering, Peking University, Beijing, 100871, China \\ Correspondence: Lisa K. Whalley (1.k.whalley@leeds.ac.uk) and Dwayne E. Heard (d.e.heard@leeds.ac.uk)
}

Received: 17 December 2019 - Discussion started: 15 January 2020

Revised: 7 April 2020 - Accepted: 29 April 2020 - Published: 12 June 2020

\begin{abstract}
Hydroxyl $(\mathrm{OH})$ and hydroperoxy $\left(\mathrm{HO}_{2}\right)$ radicals are central to the understanding of atmospheric chemistry. Owing to their short lifetimes, these species are frequently used to test the accuracy of model predictions and their underlying chemical mechanisms. In forested environments, laser-induced fluorescence-fluorescence assay by gas expansion (LIF-FAGE) measurements of $\mathrm{OH}$ have often shown substantial disagreement with model predictions, suggesting the presence of unknown $\mathrm{OH}$ sources in such environments. However, it is also possible that the measurements have been affected by instrumental artefacts, due to the presence of interfering species that cannot be discriminated using the traditional method of obtaining background signals via modulation of the laser excitation wavelength (" $\mathrm{OH}_{\text {wave"). The }}$ interference hypothesis can be tested by using an alternative method to determine the $\mathrm{OH}$ background signal, via the addition of a chemical scavenger prior to sampling of ambi-

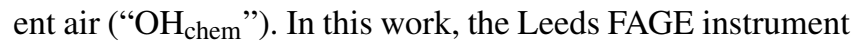
was modified to include such a system to facilitate measurements of $\mathrm{OH}_{\text {chem }}$, in which propane was used to selectively remove $\mathrm{OH}$ from ambient air using an inlet pre-injector (IPI). The IPI system was characterised in detail, and it was found that the system did not reduce the instrument sensitivity towards $\mathrm{OH}(<5 \%$ difference to conventional sampling) and was able to efficiently scavenge external $\mathrm{OH}(>99 \%)$ without the removal of $\mathrm{OH}$ formed inside the fluorescence cell $(<5 \%)$. Tests of the photolytic interference from ozone in the presence of water vapour revealed a small but potentially significant interference, equivalent to an $\mathrm{OH}$ concen-
\end{abstract}

tration of $\sim 4 \times 10^{5}$ molec. $\mathrm{cm}^{-3}$ under typical atmospheric conditions of $\left[\mathrm{O}_{3}\right]=50 \mathrm{ppbv}$ and $\left[\mathrm{H}_{2} \mathrm{O}\right]=1 \%$. Laboratory experiments to investigate potential interferences from products of isoprene ozonolysis did result in interference signals, but these were negligible when extrapolated down to ambient ozone and isoprene levels. The interference from $\mathrm{NO}_{3}$ radicals was also tested but was found to be insignificant in our system. The Leeds IPI module was deployed during three separate field intensives that took place in summer at a coastal site in the UK and both in summer and winter in the megacity of Beijing, China, allowing for investigations of ambient $\mathrm{OH}$ interferences under a wide range of chemical and meteorological conditions. Comparisons of ambient $\mathrm{OH}_{\text {chem }}$ measurements to the traditional $\mathrm{OH}_{\text {wave }}$ method

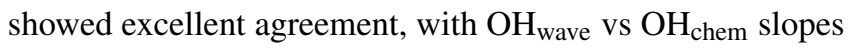
of 1.05-1.16 and identical behaviour on a diel basis, consistent with laboratory interference tests. The difference between $\mathrm{OH}_{\text {wave }}$ and $\mathrm{OH}_{\text {chem }}$ ("OH int") was found to scale nonlinearly with $\mathrm{OH}_{\text {chem }}$, resulting in an upper limit interference of $(5.0 \pm 1.4) \times 10^{6}$ molec. $\mathrm{cm}^{-3}$ at the very highest $\mathrm{OH}_{\text {chem }}$ concentrations measured $\left(23 \times 10^{6}\right.$ molec. $\left.\mathrm{cm}^{-3}\right)$, accounting for $\sim 14 \%-21 \%$ of the total $\mathrm{OH}_{\text {wave }}$ signal. 


\section{Introduction}

The removal of pollutants and greenhouse gases in the troposphere is dominated by reactions with the hydroxyl radical $(\mathrm{OH})$, which is closely coupled to the hydroperoxy radical $\left(\mathrm{HO}_{2}\right)$. Comparisons of the levels of $\mathrm{OH}$ and $\mathrm{HO}_{2}$ observed during field campaigns to the results of detailed chemical box models serve as a vital tool to assess our understanding of the underlying chemical mechanisms involved in tropospheric oxidation. Laser-induced fluorescence-fluorescence assay by gas expansion (LIF-FAGE) measurements of $\mathrm{OH}$ in forested environments have often been considerably higher than those predicted by models (Carslaw et al., 2001; Lelieveld et al., 2008; Ren et al., 2008; Hofzumahaus et al., 2009; Stone et al., 2011; Whalley et al., 2011; Wolfe et al., 2011). The difficulty in simulating radical concentrations in such environments has prompted a multitude of theoretical (Peeters et al., 2009, 2014; da Silva et al., 2010; Nguyen et al., 2010; Peeters and Muller, 2010), laboratory (Dillon and Crowley, 2008; Hansen et al., 2017), and chamber (Paulot et al., 2009; Crounse et al., 2011, 2012; Wolfe et al., 2012; Fuchs et al., 2013, 2014, 2018; Praske et al., 2015; Teng et al., 2017) studies to help explain the sources of the measurement-model discrepancy through detailed investigations of the mechanism of isoprene oxidation under low $\mathrm{NO}_{x}$ conditions, as well as other biogenic volatile organic compounds (BVOCs) (Novelli et al., 2018). However, another hypothesis is that the LIF measurements have, at least in part, suffered from an instrumental bias in these environments due to interfering species.

Early LIF measurements of $\mathrm{OH}$ suffered from significant interferences due to laser-generated $\mathrm{OH}$ from ozone photolysis in the presence of water vapour (Hard et al., 1984). While this effect has been reduced by going from 282 to $308 \mathrm{~nm}$ laser excitation of $\mathrm{OH}$, it may still be significant, especially at night or with the use of multi-pass laser set-ups (e.g. up to $\sim 4 \times 10^{6}$ molec. $\mathrm{cm}^{-3}$ in Griffith et al., 2016). Laboratory experiments conducted by Ren and co-workers using the Pennsylvania State University (PSU) LIF instrument showed negligible interferences in $\mathrm{OH}$ detection for a range of candidate species: $\mathrm{H}_{2} \mathrm{O}_{2}, \mathrm{HONO}, \mathrm{HCHO}, \mathrm{HNO}_{3}$, acetone, and various $\mathrm{RO}_{2}$ radicals (Ren et al., 2004). Observations of $\mathrm{OH}$ during the PROPHET (Program for Research on Oxidants: PHotochemistry, Emissions and Transport) field campaign in summer 1998, located in a mixed deciduous forest in Michigan, USA, revealed unusually high night-time $\mathrm{OH}$ concentrations $\left(\sim 1 \times 10^{6}\right.$ molec. $\left.\mathrm{cm}^{-3}\right)$ but measurement interferences were ruled out (Faloona et al., 2001).

However, the results of more recent studies conducted in forested environments have meant that interferences in the measurement of $\mathrm{OH}$ by LIF-FAGE have been revisited. The usual background method of this technique, where the laser wavelength is scanned off-resonance from an $\mathrm{OH}$ tran-

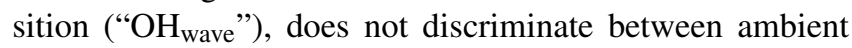
(i.e. "real") $\mathrm{OH}$ and either $\mathrm{OH}$ formed inside the FAGE cell (e.g. laser- or surface-generated $\mathrm{OH}$ or via unimolecular decomposition in the gas phase to form $\mathrm{OH}$ ) or fluorescence from other species at $\lambda \sim 308 \mathrm{~nm}$ (e.g. naphthalene, $\mathrm{SO}_{2}$ ), although it is possible to correct for such effects providing the interference has been previously characterised (Martinez et al., 2004; Ren et al., 2004; Griffith et al., 2013; Fuchs et al., 2016). There is an alternative, chemical method (" $\mathrm{OH}_{\mathrm{chem}}$ ") for obtaining the $\mathrm{OH}$ background signal in LIF instruments that allows for interference signals to be determined without their prior characterisation, in order to rule out possible artefacts from unknown species. The $\mathrm{OH}_{\text {chem }}$ method involves the addition of a high concentration of an $\mathrm{OH}$ scavenger, such as perfluoropropene $\left(\mathrm{C}_{3} \mathrm{~F}_{6}\right)$ or propane, just before the FAGE inlet. Ambient $\mathrm{OH}$ is quickly titrated away by fast reaction with the scavenger, but any interference should remain in the fluorescence signal, although this must be corrected for reaction of any internally generated $\mathrm{OH}$ with the scavenger inside the FAGE cell.

Several LIF-FAGE groups have now made efforts to validate ambient $\mathrm{OH}$ measurements through incorporation of the alternative $\mathrm{OH}_{\text {chem }}$ technique, which was first applied for continuous $\mathrm{OH}$ measurements by Mao et al. (2012). Since then, field studies of $\mathrm{OH}$ measurement interferences have been conducted in forested (Griffith et al., 2013; Novelli et al., 2014a, 2017; Feiner et al., 2016; Lew et al., 2019), rural (Fuchs et al., 2017; Tan et al., 2017), suburban (Tan et al., 2018, 2019), urban (Ren et al., 2013; Brune et al., 2016; Griffith et al., 2016), and coastal (Novelli et al., 2014a; Mallik et al., 2018) locations. Substantial improvement in measurement-model agreement has been possible when $\mathrm{OH}$ backgrounds were determined chemically, especially in forested environments, suggesting that understanding of tropospheric oxidation processes in such regions may be better than previously thought (Mao et al., 2012; Hens et al., 2014; Feiner et al., 2016). This is further supported by the positive identification of two new $\mathrm{OH}$ interference candidates in laboratory experiments, namely intermediates in alkene ozonolysis reactions, which may (Novelli et al., 2014b, 2017; Rickly and Stevens, 2018) or may not (Fuchs et al., 2016) be related to stabilised Criegee intermediates (SCIs), and the $\mathrm{NO}_{3}$ radical (Fuchs et al., 2016), although for all cases the observed interferences cannot explain the magnitudes of the $\mathrm{OH}$ background signals under ambient conditions. The trioxide species, $\mathrm{ROOOH}$, has also been postulated to explain elevated $\mathrm{OH}$ backgrounds in LIF-FAGE measurements made in forested regions (Fittschen et al., 2019).

However, it is not known whether other LIF instruments suffer the same levels of interference, which are likely highly dependent on cell design and operating parameters, especially the residence time of air between sampling and detection (Novelli et al., 2014a; Fuchs et al., 2016; Rickly and Stevens, 2018). Considering the bespoke nature of LIFFAGE instruments, those of different groups share the same main features but differ in many aspects, such as inlet size and shape, or whether the laser crosses the detection axis 
once (i.e. single-pass) or multiple times (multi-pass). As a result, the magnitude of any interference is likely to vary significantly between different instruments. Because of this, a general recommendation of the 2015 International $\mathrm{HO}_{x}$ Workshop (Hofzumahaus and Heard, 2016) was that different groups should incorporate their own chemical scavenger system for use in ambient $\mathrm{OH}$ measurements and to test interferences in the laboratory.

Following this recommendation, the Leeds ground-based FAGE instrument was modified to incorporate a chemical scavenger system, through the addition of an inlet preinjector (IPI). In this work, we describe the design of the IPI system and its thorough characterisation in terms of sensitivity and the degree of external and internal $\mathrm{OH}$ removal. Following this, we present the results of interference testing experiments performed using the IPI system, in which we investigated interferences from $\mathrm{O}_{3}+\mathrm{H}_{2} \mathrm{O}$, isoprene ozonolysis, and $\mathrm{NO}_{3}$ radicals. Finally, we demonstrate the use of the optimised IPI system for measurements of ambient $\mathrm{OH}$ made during three separate field campaigns in the UK and China, which encompassed a wide range of chemical and meteorological conditions.

\section{Methodology}

\subsection{Overview of the Leeds ground-based FAGE instrument}

The University of Leeds ground-based FAGE instrument, described in detail elsewhere (Creasey et al., 1997a; Whalley et al., 2010, 2013), has participated in 24 intensive field campaigns since its initial deployment in 1996. Measurements of $\mathrm{OH}, \mathrm{HO}_{2}$, and, more recently, $\mathrm{RO}_{2}$ radicals (Whalley et al., 2013) have been made in a variety of locations, ranging from pristine marine boundary layer (Creasey et al., 2003; Whalley et al., 2010), tropical rainforest (Whalley et al., 2011), and polar (Bloss et al., 2007) environments to coastal (Smith et al., 2006) and semi-polluted regions (Creasey et al., 2001), as well as urban areas (Heard et al., 2004; Emmerson et al., 2007), including a highly polluted megacity (Lee et al., 2016; Whalley et al., 2016).

Ambient $\mathrm{OH}$ is measured using laser-induced fluorescence. Briefly, ambient air is drawn through a $1.0 \mathrm{~mm}$ diameter pinhole in a conical turret inlet $(4 \mathrm{~cm}$ length, $3.4 \mathrm{~cm}$ ID; Fig. 1) at $\sim 7 \mathrm{slm}$ into a stainless steel fluorescence cell, held at $\sim 2 \mathrm{hPa}$ using a Roots blower (Leybold RUVAC WAU 1001) backed by a rotary pump (Leybold SOGEVAC SV200). An all solid-state laser system is used to excite $\mathrm{OH}$ via the $A^{2} \Sigma^{+}\left(v^{\prime}=0\right) \leftarrow X^{2} \Pi_{3 / 2}\left(v^{\prime \prime}=0\right)$ electronic transition at $\lambda=308 \mathrm{~nm}\left(\mathrm{HO}_{2}\right.$ is measured by conversion to $\mathrm{OH}$ using NO; see details below). The resultant fluorescence at $308 \mathrm{~nm}$ is detected by a micro-channel plate photomultiplier (MCP, Photek PMT325/Q/BI/G with $10 \mathrm{~mm}$ diameter photocathode) equipped with a $50 \mathrm{~ns}$ gating unit (Photek GM10-

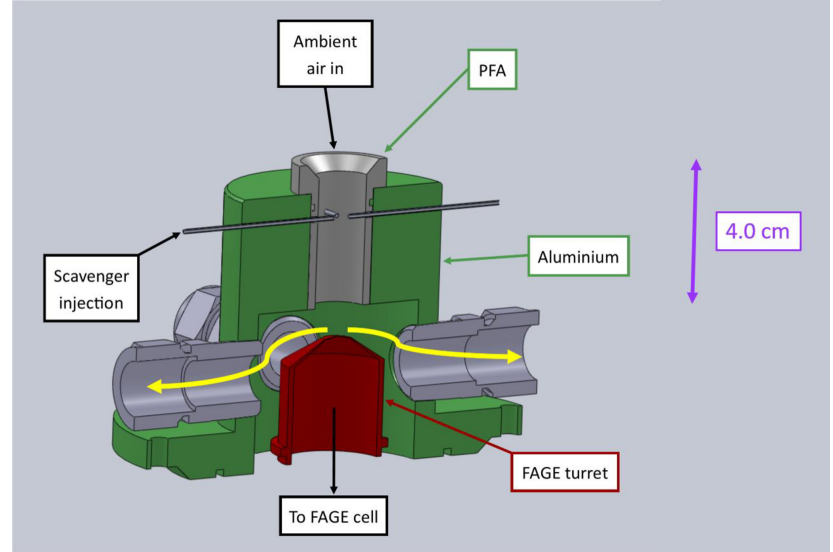

Figure 1. Labelled SolidWorks model of the Leeds inlet pre-injector (IPI). The scavenger is injected into the centre of the perfluoroalkoxy (PFA) flow tube via four $0.25 \mathrm{~mm}$ ID needles. The thick yellow arrows indicate the direction of the sheath flow.

50) and a $2 \mathrm{GHz} 20 \mathrm{~dB}$ gain amplifier (Photek PA200-10), and the signal is analysed by gated photon counting (Whalley et al., 2010). The background signal is normally obtained by scanning the laser wavelength off-resonance from the $\mathrm{OH}$ transition line, yielding the measurement commonly referred to as $\mathrm{OH}_{\text {wave }}$ :

$\left[\mathrm{OH}_{\text {wave }}\right]=C_{\mathrm{OH}} \times\left(S_{\mathrm{Online}}^{\mathrm{OH}}-S_{\mathrm{Offline}}^{\mathrm{OH}}\right)=C_{\mathrm{OH}} \times S^{\mathrm{OH}}$,

where $C_{\mathrm{OH}}$ is the instrument calibration factor for $\mathrm{OH}$ and $S_{\text {online }}^{\mathrm{OH}}$ and $S_{\text {offline }}^{\mathrm{OH}}$ are the OH LIF signals at on- and offresonance wavelengths, respectively. Similarly, the alternative measurement known as $\mathrm{OH}_{\text {chem }}$ is defined as follows:

$$
\begin{aligned}
& {\left[\mathrm{OH}_{\mathrm{chem}}\right]=C_{\mathrm{OH}} \times\left(S_{\mathrm{Online}}^{\mathrm{OH}}-S_{\mathrm{online}}^{\mathrm{OH}} \text { scavenger }\right),} \\
& =C_{\mathrm{OH}} \times S_{\text {scavenger }}^{\mathrm{OH}},
\end{aligned}
$$

where $S_{\text {online, scavenger }}^{\mathrm{OH}}$ is the $\mathrm{OH}$ signal measured at an onresonance wavelength but in the presence of a scavenger.

$\mathrm{HO}_{2}$ is detected via its conversion to $\mathrm{OH}$ following the addition of NO (BOC, $99.95 \%$, and Messer, 99.95\%). Although not reported here, $\mathrm{RO}_{2}$ radicals are measured using the $\mathrm{RO}_{x}$ LIF method (Fuchs et al., 2008; Whalley et al., 2013), in which their reactions with $\mathrm{NO}$ and $\mathrm{CO}$ (BOC, $5 \%$ in $\mathrm{N}_{2}$, and Messer, $10 \%$ in $\mathrm{N}_{2}$ ) result in conversion initially to $\mathrm{OH}$ (using $\mathrm{NO} ; \mathrm{RO}_{2} \rightarrow \mathrm{HO}_{2} \rightarrow \mathrm{OH}$ ) and subsequently back to $\mathrm{HO}_{2}$ (using $\mathrm{CO} ; \mathrm{OH} \rightarrow \mathrm{HO}_{2}$ ) that is then detected as described above (via addition of $\mathrm{NO}$ inside the FAGE cell; $\mathrm{HO}_{2} \rightarrow \mathrm{OH}$ ). The $\mathrm{NO}$ and $\mathrm{CO}$ are delivered using mass flow controllers (MFC, MKS Instruments 1179A series), which, unless otherwise stated, were also used to control all other gas flows described in this work. The Leeds FAGE instrument features two fluorescence cells, where laser light ( $\sim 10-20 \mathrm{~mW}$ at $308 \mathrm{~nm}$, supplied at a pulse repetition frequency of $5 \mathrm{kHz}$ via an optical fibre) enters each cell in 
series. For normal operation in the field, the first cell $\left(\mathrm{HO}_{x}\right)$ measures $\mathrm{OH}$ and $\mathrm{HO}_{2}$ (low $\mathrm{NO}$ flow, $5 \mathrm{sccm} ; \mathrm{RO}_{2}$ interference minimised) sequentially, while the second cell $\left(\mathrm{RO}_{x}\right)$ measures $\mathrm{HO}_{2}^{*}$ (high $\mathrm{NO}$ flow, $50 \mathrm{sccm} ; \mathrm{RO}_{2}$ interference maximised) and then total $\mathrm{RO}_{2}$ (Fuchs et al., 2008; Whalley et al., 2013).

Calibration of the FAGE instrument is achieved by supplying known radical concentrations via a turbulent flow tube (known in Leeds as the "wand") held at $\sim 45^{\circ}$ to the instrument inlet, where $\mathrm{OH}$ and $\mathrm{HO}_{2}$ are formed in a $1: 1$ ratio (Fuchs et al., 2011) by the photolysis of water vapour at $184.9 \mathrm{~nm}$ using a $\mathrm{Hg}(\mathrm{Ar})$ pen-ray lamp (LOT LSP035) in an excess flow $(40 \mathrm{slm})$ of humidified ultra-high-purity air (BOC, BTCA 178, and Messer, 20.5\% $\mathrm{O}_{2}$ in $\mathrm{N}_{2}$ ). Chemical actinometry is performed via the photolysis of $\mathrm{N}_{2} \mathrm{O}$ (BOC, medical-grade $98 \%$ ) to measure the product of lamp flux and photolysis exposure time to enable calculation of radical concentrations (Edwards et al., 2003; Faloona et al., 2004). The calibration of $\mathrm{OH}$ using the water vapour photolysis method has been validated by comparison with other methods, for example the kinetic decay of hydrocarbons (Winiberg et al., 2015).

\subsection{Inlet pre-injector (IPI) design}

The Leeds inlet pre-injector (Fig. 1) is similar in concept to the design of Mao et al. (2012) and consists of a $4.0 \mathrm{~cm}$ length, $1.9 \mathrm{~cm}$ ID perfluoroalkoxy (PFA) cylinder embedded inside an aluminium housing, which seals to the FAGE cell via an O-ring base. The scavenger is injected into the centre of the PFA flow tube via four $0.25 \mathrm{~mm}$ ID needles, $4.0 \mathrm{~cm}$ above the FAGE inlet. The low bore capillary tubing increases the pressure inside the needles, which facilitates mixing of the scavenger into the ambient air stream. In this work propane (BOC, research-grade $99.95 \%$, and Messer, $99.995 \%$ ) was used as the main $\mathrm{OH}$ chemical scavenger, with similar results (see Sect. 3.1.2) obtained for $\mathrm{C}_{3} \mathrm{~F}_{6}$ (Sigma-Aldrich, 99\%). Based on previous investigations of OH interferences (Stevens et al., 1994; Dubey et al., 1996; Faloona et al., 2001; Ren et al., 2004; Mao et al., 2012; Griffith et al., 2013; Rickly and Stevens, 2018), $\mathrm{C}_{3} \mathrm{~F}_{6}$ was used initially as it reacts quickly and selectively with $\mathrm{OH}$ $\left(k_{298}=2.2 \times 10^{-12} \mathrm{~cm}^{3}\right.$ molec. $^{-1} \mathrm{~s}^{-1}$ Sander et al., 2011) and does not contain any hydrogen atoms, which could serve as a source of laser-generated $\mathrm{OH}$ via abstraction by $\mathrm{O}\left({ }^{1} \mathrm{D}\right)$ atoms (Stevens et al., 1994; Dubey et al., 1996). However, $\mathrm{C}_{3} \mathrm{~F}_{6}$ must be diluted in an inert gas before it can be flowed through MFCs, and its availability in the UK became limited in 2015. Following Novelli et al. (2014a), we therefore used propane for most laboratory experiments and all ambient measurements, despite the fact that it reacts more slowly with $\mathrm{OH}\left(k_{298}=1.1 \times 10^{-12} \mathrm{~cm}^{3}\right.$ molec. ${ }^{-1} \mathrm{~s}^{-1}$ Sander et al., 2011).

As shown in Fig. 2, the scavenger $(0-50 \mathrm{sccm})$ is diluted in a flow of $\mathrm{N}_{2}(500 \mathrm{sccm}, \mathrm{BOC}, 99.998 \%)$ prior to injection,

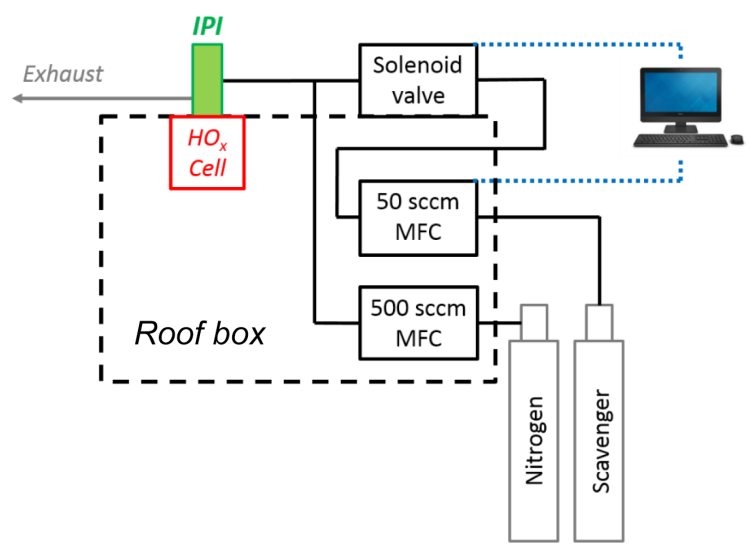

Figure 2. Diagram of the gas flows involved in IPI scavenger injection (not to scale). The two mass flow controllers (MFCs) are housed in the roof box, where the scavenger MFC $(0-50 \mathrm{sccm})$ and injection valve (in a weatherproof housing on top of the roof box) are controlled using the main FAGE PC situated in the container laboratory.

which is controlled using a solenoid valve (Metron Semiconductors). Any dead volume after the valve is purged continuously by the $\mathrm{N}_{2}$ dilution flow, using a narrow-bore injector inserted through the tee after the valve, with the injector tip placed as close to the valve orifice as possible. This enables fast flushing of the system to optimise the response time before and after scavenger injection. Incorporation of the purge system resulted in pre- and post-injection stabilisation times on the order of seconds (data not shown), minimising data loss. The valve state and scavenger flow over the course of the data acquisition cycle are controlled using a custom program nested within the FAGE software.

To reduce radical wall losses, excess ambient air is drawn through the IPI to generate a sheath flow, via four ports spaced evenly around the flow tube housing as shown in Fig. 1. This minimises the FAGE sampling of air from near the walls of the cylinder, housing, and turret. The total flow rate through the IPI is $32 \mathrm{slm}$, of which $7 \mathrm{slm}$ is sampled by the FAGE cell and the remainder of the flow is maintained by a vacuum pump (Agilent Technologies IDP-3 Dry Scroll Pump) and measured volumetrically using a rotameter (Brooks 2520, 4-50 L min${ }^{-1}$ ).

During interference testing experiments using the IPI system (Sect. 3.2), ozone and water vapour concentrations were measured using a commercial UV absorption instrument (Thermo Environmental Instruments Inc. 49C) and a chilled mirror dew point hygrometer (General Eastern 1311DR sensor and $4 \times 4$ Optica), respectively. 
Table 1. Overall meteorological and chemical conditions encountered during each field campaign, including example VOCs. Values are given as the median of all points that coincide with IPI sampling periods, except for $J\left(\mathrm{O}^{1} \mathrm{D}\right)$ and $\mathrm{O}_{3}$, which are reported as diurnally averaged maxima.

\begin{tabular}{|c|c|c|c|}
\hline & $\mathrm{ICOZA}^{\mathrm{a}}$ & AIRPRO winter ${ }^{b}$ & AIRPRO summer \\
\hline Dates (IPI sampling) & 3-8 and 12-16 Jul 2015 & 2-7 Dec 2016 & 23 May-25 Jun 2017 \\
\hline Location & $52^{\circ} 57^{\prime} 02^{\prime \prime} \mathrm{N}, 1^{\circ} 07^{\prime} 19^{\prime \prime} \mathrm{E}$ & \multicolumn{2}{|c|}{$39^{\circ} 58^{\prime} 28^{\prime \prime} \mathrm{N}, 116^{\circ} 22^{\prime} 16^{\prime \prime} \mathrm{E}$} \\
\hline \multicolumn{4}{|l|}{ Meteorological } \\
\hline Temperature $\left({ }^{\circ} \mathrm{C}\right)$ & 16 & 6.1 & 26 \\
\hline $\mathrm{H}_{2} \mathrm{O}(\%)$ & 1.5 & 0.4 & 1.6 \\
\hline Wind speed $\left(\mathrm{ms}^{-1}\right)$ & 5.8 & 0.9 & 0.4 \\
\hline$J\left(\mathrm{O}^{1} \mathrm{D}\right)\left(10^{-6} \mathrm{~s}^{-1}\right)$ & 16. & 3.5 & 19 \\
\hline \multicolumn{4}{|l|}{ Chemical } \\
\hline $\mathrm{O}_{3}(\mathrm{ppbv})$ & 42 & 15 & 90 \\
\hline NO (ppbv) & 0.19 & 22. & 0.81 \\
\hline $\mathrm{NO}_{2}(\mathrm{ppbv})$ & 2.2 & 33 & 17 \\
\hline $\mathrm{CO}(\mathrm{ppbv})$ & 100 & 1120 & 460 \\
\hline Propane (ppbv) & 0.26 & 6.2 & 3.8 \\
\hline Isoprene (ppbv) & 0.02 & 0.07 & 0.38 \\
\hline Benzene (ppbv) & 0.03 & 1.4 & 0.46 \\
\hline$k^{\prime} \mathrm{OH}\left(\mathrm{s}^{-1}\right)$ & 4.4 & 38 & 25 \\
\hline
\end{tabular}

a Integrated Chemistry of OZone in the Atmosphere. ${ }^{\mathrm{b}}$ An integrated study of AIR pollution PROcesses in Beijing (Shi et al., 2019).

\subsection{Field measurement sites}

Ambient measurements of $\mathrm{OH}_{\text {wave }}$ and $\mathrm{OH}_{\text {chem }}$ were made using the Leeds IPI-FAGE instrument during three separate intensive field campaigns in different locations and seasons. This allowed for the investigation of potential $\mathrm{OH}$ interferences under markedly contrasting conditions. For all three field campaigns, measurements of $\mathrm{OH}, \mathrm{HO}_{2}$, and partially speciated $\mathrm{RO}_{2}$ were made using the Leeds FAGE instrument ( $4 \mathrm{~m}$ above ground level), operated in the sequential detection modes described in Sect. 2.1 (Whalley et al., 2013). Total $\mathrm{OH}$ reactivity, $k_{\mathrm{OH}}^{\prime}$, was also measured, using the laser flash photolysis-LIF instrument described in detail by Stone et al. (2016). A range of supporting chemical, aerosol, and meteorological parameters were measured, with instruments situated either in buildings or shipping containers at each of the two sites. Gas-phase chemical observations included water vapour, $\mathrm{NO}_{x}, \mathrm{NO}_{y}, \mathrm{O}_{3}, \mathrm{CO}, \mathrm{SO}_{2}, \mathrm{HONO}, \mathrm{HCHO}$ (Cryer, 2016), $\mathrm{ClNO}_{2}$, VOCs, and OVOCs. Photolysis rates $(J)$ for a variety of species, including $\mathrm{O}_{3}\left(\rightarrow \mathrm{O}\left({ }^{1} \mathrm{D}\right)\right), \mathrm{NO}_{2}, \mathrm{HCHO}$, $\mathrm{HONO}$, and $\mathrm{ClNO}_{2}$, were measured using a $2 \pi$ spectral radiometer $(2 \pi$ actinic receiver optic, Meteorologie Consult $\mathrm{GmbH}$, coupled to an Ocean Optics QE Pro spectrometer), and $J\left(\mathrm{O}^{1} \mathrm{D}\right)$ was also measured using a $2 \pi$ filter radiometer (Meteorologie Consult GmbH) (Bohn et al., 2008). The meteorological and chemical conditions, including some example VOCs, encountered during each campaign are summarised in Table 1 and discussed in further detail below.
The first deployment of the Leeds IPI was during the ICOZA (Integrated Chemistry of OZone in the Atmosphere) project, which took place in July 2015, at the Weybourne Atmospheric Observatory (WAO), Weybourne, located on the northern Norfolk Coast, UK $\left(52^{\circ} 57^{\prime} 02^{\prime \prime} \mathrm{N}, 1^{\circ} 07^{\prime} 19^{\prime \prime} \mathrm{E}\right.$, $15 \mathrm{~m}$ a.s.1.). The WAO is a Global Atmospheric Watch (GAW) regional station, and the site is impacted by a range of contrasting air masses, from clean Arctic air to processed emissions from the UK (e.g. London, which is located $180 \mathrm{~km} \mathrm{SSW}$ of the observatory) and northern Europe. The aim of this field campaign was to improve understanding of ozone chemistry through integrated measurements of $P\left(\mathrm{O}_{3}\right)$, i.e. the chemical or in situ ozone production rate $(\mathrm{OPR})(\mathrm{Ca}-$ zorla and Brune, 2010; Cazorla et al., 2012), with comparisons to a range of other observational and model approaches. Two continuous IPI sampling periods were conducted in the middle of the campaign, separated by a few days (3-8 and 12-16 July), with a total of $9 \mathrm{~d}$ where $\mathrm{OH}_{\text {chem }}$ measurements are available around midday (fully continuous measurements were not always possible due to multiple instrument problems, e.g. cell blockages and laser power drops). For other times, only measurements of $\mathrm{OH}_{\text {wave }}$ are available. During the IPI sampling periods, power cuts on the nights of 3-4 and 6-7 July resulted in extended data loss.

In general, the ICOZA campaign was characterised (Table 1$)$ by moderate temperatures $\left(16^{\circ} \mathrm{C}\right.$ median $)$, high humidity (RH $\sim 80 \%$ ), and strong wind speeds $\left(\sim 6 \mathrm{~m} \mathrm{~s}^{-1}\right.$ ), as might be expected at a temperate, coastal location in the 
summertime. The predominant wind sector, based on wind direction measurements at the site, was westerly $(\sim 30 \%)$, followed by southwesterly $(\sim 20 \%)$ and southerly $(\sim 15 \%)$. Back-trajectory analysis showed that during IPI sampling periods, the site was predominantly under the influence of Atlantic air (Cryer, 2016). These air masses had spent a considerable amount of time ( $\sim 1 \mathrm{~d})$ over the UK, often encountering emissions from urban areas, which underwent photochemical ageing during their transport to the WAO site. Overall, the levels of pollution observed at the site were moderate, and the lowest of the three field campaigns discussed in this work (Table 1), and levels of isoprene were low. However, ozone mixing ratios were relatively high, with a dielaverage maximum of $\sim 40 \mathrm{ppbv}$, driven in part by strong UV and near-UV radiation.

The Leeds IPI was deployed during another two campaigns at the Institute of Atmospheric Physics (IAP, $39^{\circ} 58^{\prime} 36.06^{\prime \prime} \mathrm{N}, 116^{\circ} 22^{\prime} 53.69^{\prime \prime} \mathrm{E}$ ), an urban site in Beijing, China, during winter (November-December) 2016 and summer (May-June) 2017, as part of the AIRPRO (an integrated study of AIR pollution PROcesses in Beijing) project. AIRPRO is part of the wider APHH (Air Pollution and Human Health in a Chinese megacity) project (Shi et al., 2019), a joint UK-China programme. The aims of AIRPRO included the assessment of how pollutants are transformed and removed through transport, chemical, and photolytic processes, with a particular emphasis on the identification of the dominant oxidative degradation pathways (i.e. the relative importance of reactions with $\mathrm{OH}, \mathrm{NO}_{3}$, and $\mathrm{O}_{3}$ ). The AIRPRO project allowed for the assessment of $\mathrm{OH}$ measurement interferences under the highly polluted conditions of the megacity Beijing, situated on the heavily industrialised North China Plain. In winter, the site is impacted by urban and regional anthropogenic emissions, in particular those from the combustion of fossil fuels for residential heating. During summer, the site is subject to additional biogenic influences, and strong photochemical activity results in high rates of ozone production. In winter, $\mathrm{OH}_{\text {wave }}$ and $\mathrm{OH}_{\text {chem }}$ were measured simultaneously for $6 \mathrm{~d}$ of the campaign. In summer, almost 1 month of near-continuous IPI data are available, with $1 \mathrm{~d}$ of interruptions due to IPI testing (see Sect. 3.1.2).

For both AIRPRO field intensives, the predominant wind sectors were westerly and southerly-southeasterly, which generally result in higher pollutant concentrations (Chen et al., 2015). Indeed, the two campaigns were subject to high pollutant concentrations, as illustrated by the elevated levels of $\mathrm{NO}_{2}, \mathrm{CO}$, propane, benzene, and $k_{\mathrm{OH}}^{\prime}$, many of which were over an order of magnitude higher than ICOZA (Table 1). In addition, the biogenic influence during summer is clear from the relatively high isoprene concentrations observed, $\sim 0.4 \mathrm{ppbv}$ on average but reaching up to $7.9 \mathrm{ppbv}$, a level considerably higher than those observed in some forested environments. Despite similar $J\left(\mathrm{O}^{1} \mathrm{D}\right)$ values between ICOZA and AIRPRO summer, the higher VOC load- ings during the latter resulted in increased production of ozone ( 90 ppbv diurnally averaged maximum). In contrast, AIRPRO winter was characterised by small ozone mixing ratios (15 ppbv diurnal maximum), as a consequence of high NO levels (median $22 \mathrm{ppbv}$ ) and weak UV radiation. In summer, NO levels were high in the morning ( $\sim 14 \mathrm{ppbv}$ at 06:00 China standard time, CST) but surprisingly low in the afternoon, with diel-average median levels of $\sim 0.5 \mathrm{ppbv}$ (15:0018:00 CST).

For all ambient observation periods, the IPI data acquisition cycle consisted of $5 \mathrm{~min}$ of online wavelength and $30 \mathrm{~s}$ of offline wavelength (spectral background) integration, where the online period was split into 2 min of $\mathrm{OH}$ measurements and 2 min of propane addition to the IPI flow tube (chemical background), followed by 1 min of $\mathrm{HO}_{2}$ measurements (by the addition of NO to the FAGE cell). In terms of instrumental operation, the only difference between ICOZA and the AIRPRO campaigns was the use of different propane flows in the IPI. The propane concentration in the IPI flow tube was $\sim 110$ ppmv $\left(k_{\mathrm{OH}}^{\prime} \sim 3000 \mathrm{~s}^{-1}, \tau_{\mathrm{OH}} \sim 0.3 \mathrm{~ms}\right)$ during ICOZA and AIRPRO winter, but after internal removal experiments revealed that the propane level could be increased further (see Sect. 3.1.3), a 10-fold higher concentration $(\sim 1100 \mathrm{ppmv})$, resulting in a concomitant reduction in the $\mathrm{OH}$ lifetime, was used for the AIRPRO summer campaign. On $1 \mathrm{~d}$ with high ozone (up to $\sim 80 \mathrm{ppbv}$ ) and moderate isoprene $(\sim 0.5-1 \mathrm{ppbv})$ levels, the propane mixing ratio was reduced to $\sim 110 \mathrm{ppmv}$, but this had no observable effect on the background signals obtained for the summer data. All ambient $\mathrm{OH}_{\text {wave }}$ data presented here have been corrected for the known interference from $\mathrm{O}_{3}$ in the presence of $\mathrm{H}_{2} \mathrm{O}$ vapour (see Sect. 3.2.1).

\section{Results}

\subsection{IPI characterisation}

\subsubsection{Sensitivity}

The presence of additional surfaces in the IPI system may result in radical wall losses and therefore reduce the overall FAGE instrument sensitivity. To test for potential $\mathrm{OH}$ losses in the IPI flow tube, $\mathrm{OH}$ radicals were generated using a $184.9 \mathrm{~nm} \mathrm{Hg}$ lamp placed $\sim 19 \mathrm{~cm}$ from the instrument inlet, so that ambient air with elevated radical concentrations $(\sim 2-$ $7 \times 10^{7}$ molec. $\mathrm{cm}^{-3}$ ) was sampled, alternating between IPI and non-IPI sampling (Fig. 3), where for the latter the entire IPI assembly was removed. The dominant source of $\mathrm{OH}$ was the photolysis of ambient water vapour at $184.9 \mathrm{~nm}$. In these experiments, the Hg lamp was placed sufficiently far away from each inlet within a large tent enclosure on the container roof, such that it could be assumed that $\mathrm{OH}$ concentrations were uniform in the region the inlet sampled from. Otherwise, the difference in inlet height between IPI and non-IPI 


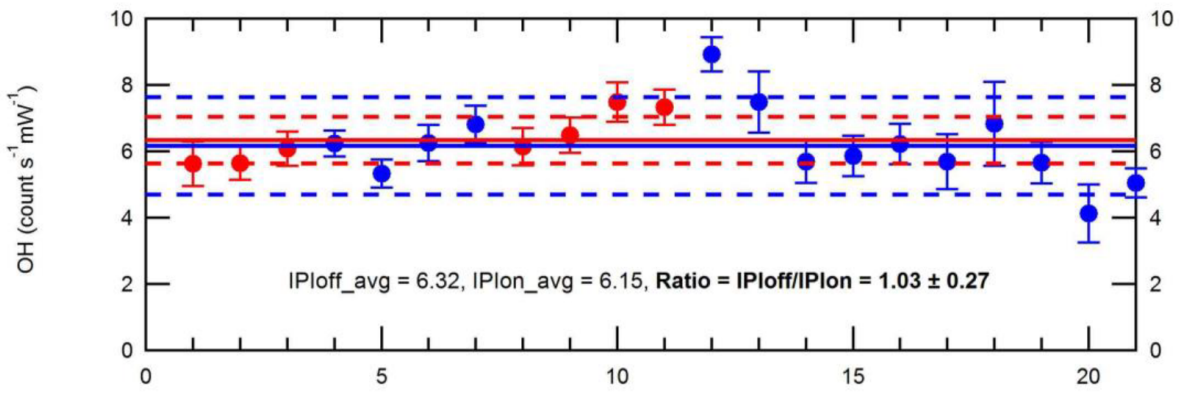

Loop number
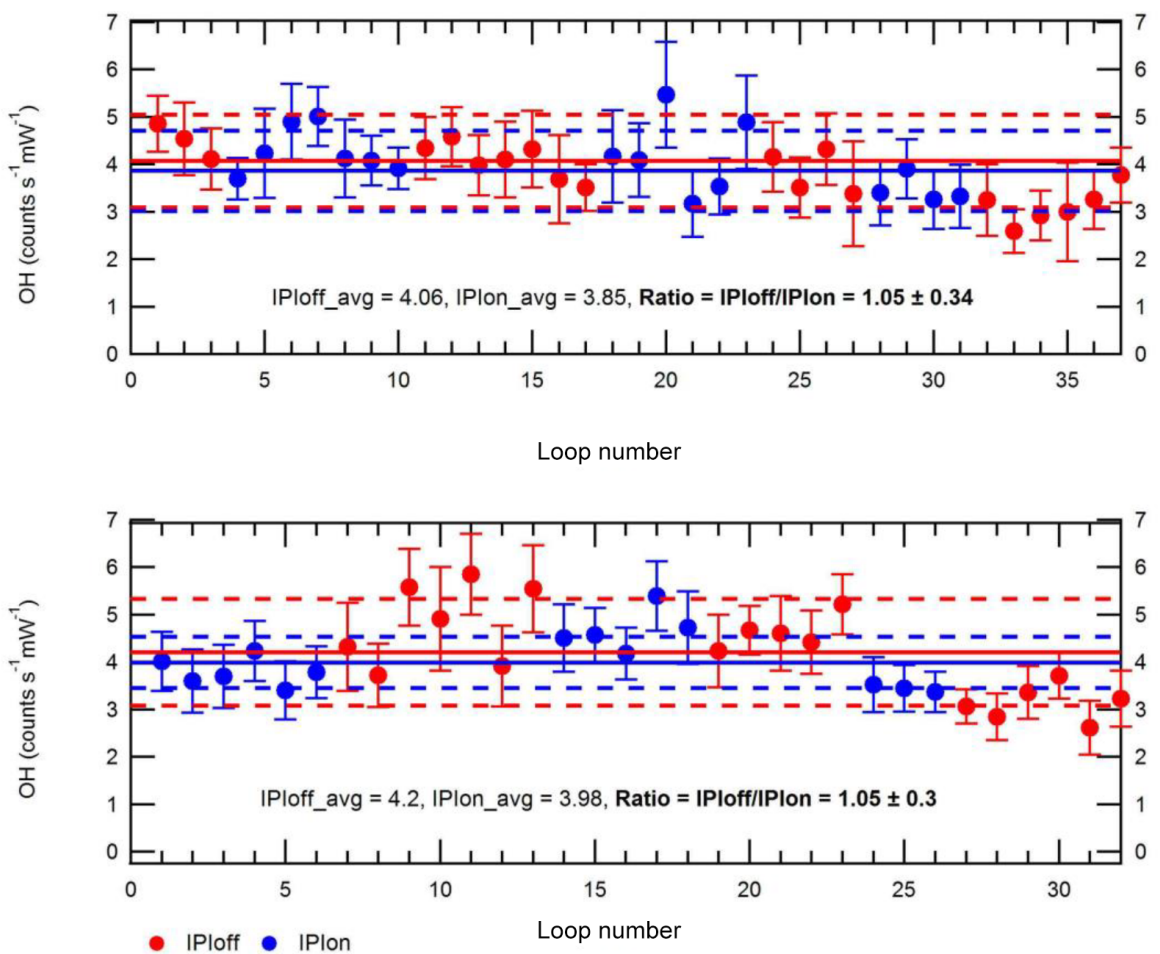

Figure 3. Testing of $\mathrm{OH}$ losses in the IPI system. Each panel shows repeat measurements of OH signals $( \pm 2 \sigma)$ over the course of $1 \mathrm{~d}$, where high $\mathrm{OH}$ concentrations were generated using a $184.9 \mathrm{~nm} \mathrm{Hg} \mathrm{lamp} \mathrm{placed} \mathrm{near} \mathrm{the} \mathrm{instrument} \mathrm{inlet.} \mathrm{Blue} \mathrm{and} \mathrm{red} \mathrm{markers} \mathrm{denote} \mathrm{individual}$ measurements (one measurement "loop", i.e. one wavelength online-offline cycle) performed with ("IPIon") and without ("IPIoff") the IPI system, respectively. Solid lines correspond to the average signals for each day, with $2 \sigma$ standard deviations (SD) shown by the dashed lines.

sampling may have resulted in different $\mathrm{OH}$ concentrations being sampled, e.g. due to differences in $\mathrm{O}_{3}$ absorption at $184.9 \mathrm{~nm}\left(\mathrm{O}_{3}\right.$ has a high cross section at this wavelength), which would affect the light flux at the point of sampling and hence the concentration of $\mathrm{OH}$ generated. Since ambient variability (e.g. in $\mathrm{NO}_{x}$ levels) also affects the atmospheric radical concentrations, the IPI-non-IPI cycle was repeated several dozen times on 3 different days within the tent enclosure to ensure sufficient averaging of the results. Any differences in wind speed or direction during the different days are not important because of the tent enclosure. Based on the averages for each set of repeat measurements in Fig. 3, these experiments yield a mean $\pm 2 \sigma$ IPIoff/IPIon ratio of
$1.043 \pm 0.023$, i.e. a $<5 \%$ sensitivity reduction due to the presence of the IPI. While $\mathrm{HO}_{2}$ loss was not tested, the relative sensitivity is assumed to be closer to unity since it is less reactive than $\mathrm{OH}$. In either case, the correction is smaller than the total instrumental uncertainty $(\sim 26 \%$ at $2 \sigma)$, and as such no corrections were applied to $\mathrm{OH}$ or $\mathrm{HO}_{2}$ calibration factors for the final workup of ambient data collected during IPI sampling periods. In other words, we assume negligible transmission losses within the IPI, and the $\mathrm{OH}$ calibration factor we applied to ambient data was the same for (1) $\mathrm{OH}_{\text {wave }}$ without IPI sampling, (2) $\mathrm{OH}_{\text {wave }}$ during IPI sampling, and (3) $\mathrm{OH}_{\text {chem }}$ during IPI sampling. However, it 
should be noted that in the field, calibrations are normally carried out without the IPI system present.

The lack of $\mathrm{OH}$ loss in the IPI system is further supported by another test conducted in the field during the summer 2017 AIRPRO campaign, where on $1 \mathrm{~d}$ of the campaign sequential measurements of $\mathrm{OH}_{\text {wave }}$ were taken with and without the IPI assembly present. While this was not a formal intercomparison, the summer 2017 campaign provided ideal conditions to assess IPI losses, considering the very high radical concentrations observed $(\mathrm{OH}$ was frequently $>1 \times 10^{7}$ molec. $\mathrm{cm}^{-3}$ ) in Beijing and thus a good signal-tonoise ratio. The results of this experiment are shown for $\mathrm{OH}$ in Fig. 4. It can be seen that if no correction for a reduction in sensitivity is applied, adjacent IPIoff and IPIon periods of data are qualitatively in agreement, with no discontinuities in the temporal profile, implying that the IPI sensitivity loss is close to zero under field operating conditions. Similar results were obtained for $\mathrm{HO}_{2}$ (data not shown).

\subsubsection{External OH removal}

The external $\mathrm{OH}$ removal efficiency in the IPI system is controlled by the injection height, the choice of scavenger (i.e. the rate coefficient of the reaction of scavenger with $\mathrm{OH}$ ), the scavenger and $\mathrm{N}_{2}$ dilution gas flows delivered to the injectors, and the sheath flow. A key requirement here is efficient mixing of the scavenger into the ambient air stream, which is difficult considering the fast flow rate and hence short residence time of air in the IPI flow tube. Additionally, it is important to consider that some reaction of the scavenger may occur inside the fluorescence chamber (internal $\mathrm{OH}$ removal, Sect. 3.1.3). This would give rise to a positive bias in ambient $\mathrm{OH}$ concentration measurements made using the $\mathrm{OH}_{\text {chem }}$ method, as internal $\mathrm{OH}$ removal could result in loss of interfering $\mathrm{OH}$ and therefore an apparent reduction in the true background signal.

External $\mathrm{OH}$ removal experiments were performed by supplying known concentrations of $\mathrm{OH}$ and $\mathrm{HO}_{2}$ to the instrument using the calibration wand described in Sect. 2.1. However, in contrast to normal calibration procedures where the wand is held at $45^{\circ}$ to the pinhole (to overfill the pinhole and minimise sampling of pockets of air which may have been in contact with the metal pinhole surface), IPI characterisation experiments were performed with the wand positioned parallel to the direction of flow within the IPI (i.e. $90^{\circ}$ relative to the plane of the pinhole), with a distance of $\sim 3 \mathrm{~cm}$ between the wand exit and the PFA flow tube. The high flow through the calibration wand ( $40 \mathrm{slm}$ ) ensured that an excess of calibration gas was delivered to the IPI system (sample flow $\sim 32 \mathrm{slm}$ ).

The external $\mathrm{OH}$ removal efficiency $\left(\mathrm{RE}_{\text {external }}^{\mathrm{OH}}\right)$ may be calculated from the proportion of $\mathrm{OH}$ remaining $\left(R_{\text {external }}^{\mathrm{OH}}\right)$ after injection of the scavenger, obtained from the ratio of the $\mathrm{OH}$ signals in the presence $\left(S_{\text {scavenger }}^{\mathrm{OH}}\right)$ and absence $\left(S^{\mathrm{OH}}\right)$ of the scavenger:

$R_{\text {external }}^{\mathrm{OH}}(\%)=100 \times S_{\text {scavenger }}^{\mathrm{OH}} / S^{\mathrm{OH}}$,

$\mathrm{RE}_{\text {external }}^{\mathrm{OH}}(\%)=100-R_{\text {external }}^{\mathrm{OH}}$.

Initial tests included variation of the $\mathrm{N}_{2}$ dilution flow; however, the $\mathrm{OH}$ removal efficiency was generally low (data not shown), likely due to poor mixing of the scavenger into the sampled air when the flow rate from the injector is small. As a result, the $\mathrm{N}_{2}$ dilution was set to the maximum flow of the MFC used $(0.5 \mathrm{slm})$ for all subsequent experiments. Any further dilution of the ambient air stream would result in a loss of sensitivity towards the detection of radicals; however, at $0.5 \mathrm{slm}$ the dilution flow is virtually negligible compared to the total flow rate in the IPI system ( $32 \mathrm{slm}$ ). In other preliminary experiments, the scavenger was injected closer to the FAGE inlet $(1.0$ and $2.5 \mathrm{~cm})$, but this also resulted in poor external $\mathrm{OH}$ removal owing to the shorter residence time between scavenger injection and FAGE sampling.

The scavenging efficiency was determined for both propane and $\mathrm{C}_{3} \mathrm{~F}_{6}$, with good agreement between the two scavengers. Figure 5 shows the remaining $\mathrm{OH}$ signal as a function of the $\mathrm{OH}$ reactivity $\left(k_{\mathrm{OH}}^{\prime}=k_{\mathrm{OH}+\text { scavenger [scav- }}\right.$ enger]) calculated in the flow tube, which normalises the scavenger concentrations according to their different reaction rates with $\mathrm{OH}$. The observed removal efficiency is in broad agreement with the theoretical scavenging efficiency, based on the residence time in the flow tube $(\sim 20 \mathrm{~ms}$, assuming plug flow) and assuming perfect mixing, suggesting that in the Leeds IPI system the scavenger is well mixed into the gas sampled by the FAGE cell. An optimum removal of virtually $100 \%$ ( $\mathrm{OH}$ remaining $\pm 2 \sigma=(0.030 \pm 0.091) \%)$ was observed at $k_{\mathrm{OH}}^{\prime} \sim 3000 \mathrm{~s}^{-1}$, equivalent to $\sim 110 \mathrm{ppmv}$ $\left(2.7 \times 10^{15}\right.$ molec. $\left.\mathrm{cm}^{-3}\right)$ propane. This scavenger concentration was used for measurements of $\mathrm{OH}_{\text {chem }}$ during the summer 2015 ICOZA project and winter 2016 AIRPRO project. For the summer 2017 AIRPRO project, a 10-fold higher scavenger concentration was used ( $\sim 1100 \mathrm{ppmv}$ propane), after internal removal experiments revealed no loss of internal $\mathrm{OH}$ at this higher concentration, as discussed in detail in the next section.

\subsubsection{Internal OH removal}

Internal removal of $\mathrm{OH}$ was quantified by Mao et al. (2012) after forming $\mathrm{OH}$ inside the PSU ground-FAGE cell using a Hg lamp and comparing the $\mathrm{OH}$ signal with and without the presence of the scavenger $\left(\mathrm{C}_{3} \mathrm{~F}_{6}\right)$, which was added externally in the IPI system. It was found that most of the internal removal occurred in the instrument inlet, rather than in the $\mathrm{OH}$ detection axis, with a total loss of $\sim 20 \%$. Internal removal was not tested in the laboratory by Novelli et al. (2014a) for the Max Planck Institute for Chemistry (MPIC) FAGE instrument, but instead they limited the scavenger (propene and propane) concentration such that the ex- 


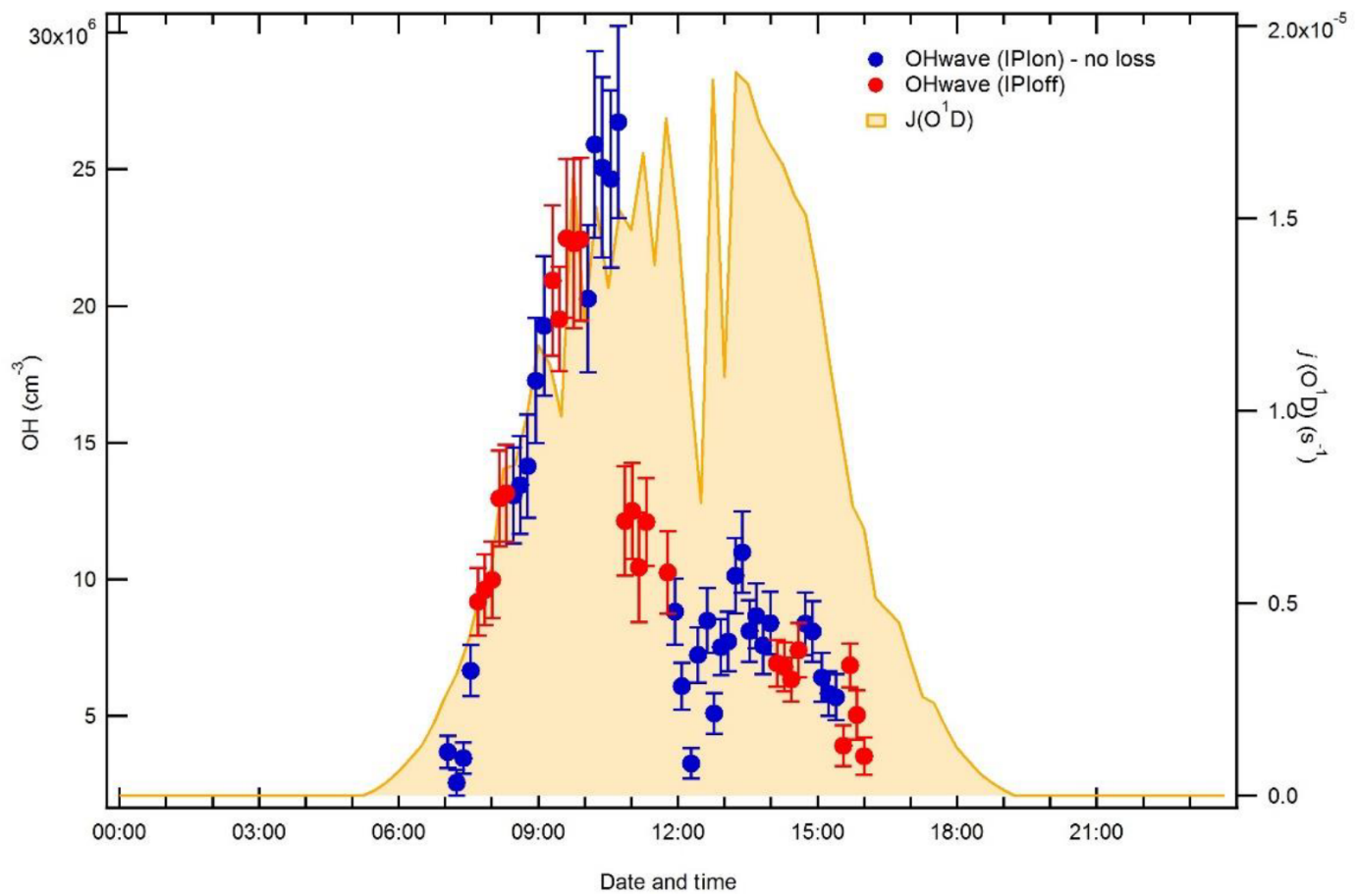

Figure 4. Time series of $\mathrm{OH}_{\text {wave }}$ concentrations in Beijing on 17 June 2017, a period of high OH levels in the summer 2017 AIRPRO (an integrated study of AIR pollution PROcesses in Beijing) campaign. Blue and red markers $( \pm 1 \sigma)$ denote observations made with and without the IPI system, respectively.

ternal $\mathrm{OH}$ removal efficiency was $<95 \%$, to minimise possible reaction of the scavenger with $\mathrm{OH}$ inside the fluorescence cell. However, during ambient, night-time tests (constant atmospheric $\mathrm{OH}$ concentration assumed), no change in the $\mathrm{OH}$ background signal was observed after increasing the scavenger concentration by a factor of 7 , providing evidence for a lack of internal removal (Novelli et al., 2014a).

In the present study, a novel approach was devised to quantify internal removal of $\mathrm{OH}$ in the Leeds IPI-FAGE instrument. First, under otherwise identical experimental conditions to those for external $\mathrm{OH}$ removal tests, sufficient $\mathrm{CO}$ (75 sccm, $95 \mathrm{ppmv}$ ) was added to the calibration wand to verify that the $\mathrm{OH}$ formed (alongside $\mathrm{HO}_{2}$ ) from the photolysis of water vapour was almost quantitatively converted to $\mathrm{HO}_{2}((98.0 \pm 0.4) \%$, data not shown $)$. Secondly, in addition to the calibration wand $\mathrm{CO}$ flow, a high flow of $\mathrm{NO}$ $(50 \mathrm{sccm})$ was injected through 0.125 in. stainless steel tubing inside the FAGE cell, with the injector tip positioned centrally just below the turret pinhole, to reconvert the $\mathrm{HO}_{2}$ back to OH for LIF detection; these experimental conditions ensured a fairly high $\mathrm{HO}_{2}$-to-OH conversion efficiency of approximately $30 \%$. In this manner, $\mathrm{OH}$ was only generated inside the FAGE cell, and not in the IPI flow tube, such that any change in the fluorescence signal could be attributed to internal reaction of $\mathrm{OH}$ with propane, rather than reaction in the flow tube. The procedure for determination of internal $\mathrm{OH}$ removal bears some resemblance to that used for ambi- ent detection of $\mathrm{RO}_{2}$ using the $\mathrm{RO}_{x} \mathrm{LIF}$ technique (Fuchs et al., 2008; Whalley et al., 2013), i.e. the external conversion of all radical species to $\mathrm{HO}_{2}$ before internal conversion to $\mathrm{OH}$ within the fluorescence cell.

The internal $\mathrm{OH}$ removal efficiency $\left(\mathrm{RE}_{\text {internal }}^{\mathrm{OH}}\right)$ was quantified in an analogous manner to the external scavenging efficiency, using the total fluorescence signal in the presence $\left(S_{\text {scavenger }}^{\mathrm{HO}_{x}}\right)$ and absence $\left(S^{\mathrm{HO}_{x}}\right)$ of the scavenger:

$$
\begin{aligned}
& R_{\text {internal }}^{\mathrm{OH}}(\%)=100 \times S_{\text {scavenger }}^{\mathrm{HO}_{x}} / S^{\mathrm{HO}_{x}}, \\
& \mathrm{RE}_{\text {internal }}^{\mathrm{OH}}(\%)=100-R_{\text {internal }}^{\mathrm{OH}} .
\end{aligned}
$$

Figure 6 shows a time series of the LIF signal during two example internal removal experiments. Here, the LIF signal represents the sum of signals from $\mathrm{OH}$ and $\mathrm{HO}_{2}$, since they are produced in a $1: 1$ ratio (Fuchs et al., 2011) in the calibration wand. For both of the propane mixing ratios used, which were shown to result in near complete external $\mathrm{OH}$ removal in Sect. 3.1.2, there was no obvious decrease in the LIF signal, indicating no significant internal removal of $\mathrm{OH}$. The average $\pm 2 \sigma$ internal $\mathrm{OH}$ removal observed for repeat experiments was $(0.0 \pm 4.0) \%$ (Table 2$)$ at a propane mixing ratio of $\sim 110$ ppmv (ICOZA and AIRPRO winter conditions). For repeat experiments at the higher propane mixing ratio used during the AIRPRO summer field campaign ( 1100 ppmv), the internal removal was still very small and almost insignificant $((2.9 \pm 6.6) \%$, Table 2$)$. The observed internal $\mathrm{OH}$ removal may be compared to that which might be expected the- 


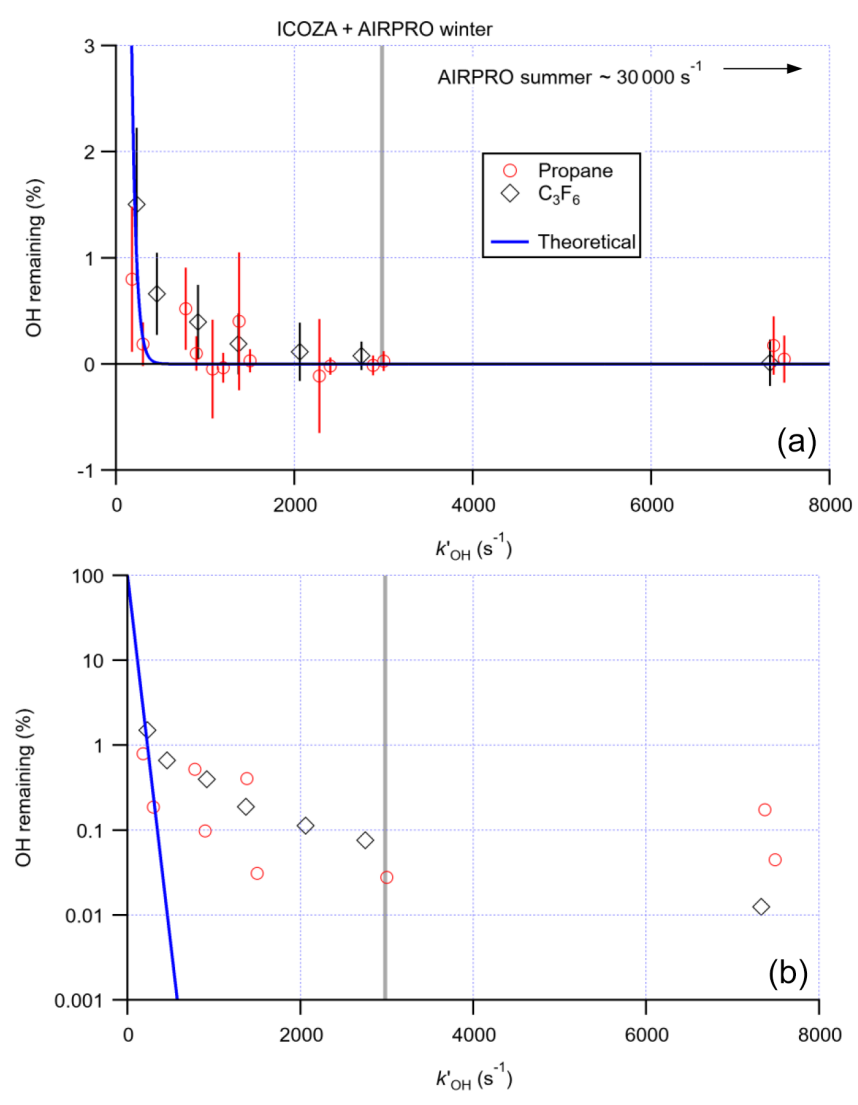

Figure 5. Proportion of the $\mathrm{OH}$ signal remaining (i.e. external $\mathrm{OH}$ removal efficiency) after addition of increasing concentrations of propane and perfluoropropene $\left(\mathrm{C}_{3} \mathrm{~F}_{6}\right)$ scavengers to the IPI flow tube, converted to equivalent $\mathrm{OH}$ reactivities $\left(k_{\mathrm{OH}}^{\prime}\right)$ to account for the different rate constants for the reaction of each scavenger with $\mathrm{OH}$ : (a) linear $y$ scale, (b) $\log y$ scale. Error bars denote the $2 \sigma \mathrm{SD}$ of repeat experiments. The blue curve corresponds to the theoretical scavenging efficiency assuming perfect mixing, using the estimated residence time, $\tau \sim 20 \mathrm{~ms}$. The propane $\mathrm{OH}$ reactivity used for the ICOZA (Integrated Chemistry of OZone in the Atmosphere) and AIRPRO winter campaigns is given but that used for AIRPRO summer is off-scale.

oretically. In the ambient pressure flow tube, a propane mixing ratio of $1100 \mathrm{ppmv}$ equates to $k_{\mathrm{OH}}^{\prime}=30000 \mathrm{~s}^{-1}$, but this is a factor of $760 / 1.5$ lower in the detection cell (i.e. the ratio of ambient to cell pressure), $59 \mathrm{~s}^{-1}$ (assuming constant gas density and no change in the $\mathrm{OH}+$ propane rate coefficient). Under normal operation, $\mathrm{NO}$ injection occurs $10.5 \mathrm{~cm}$ below the pinhole and $7.5 \mathrm{~cm}$ away from the laser axis (i.e. total of $18 \mathrm{~cm}$ between the pinhole and detection volume), with a residence time of 0.9 ms between $\mathrm{NO}$ injection and $\mathrm{OH}$ detection (Creasey et al., 1997b; Whalley et al., 2013). The gas likely slows down between pinhole sampling and NO injection but, assuming a constant gas velocity, the residence time between the pinhole and the laser axis is estimated at $\sim 2 \mathrm{~ms}$. Based on this, an internal $\mathrm{OH}$ removal efficiency of $\sim 12 \%$ is calculated, which is higher than observed, likely because the assumption of constant gas velocity is invalid (i.e. the real residence time is closer to $\sim 1 \mathrm{~ms}$ ) and mixing between $\mathrm{HO}_{2}$ and NO from the injector is not instantaneous. However, it should be noted that this calculation also neglects the fact that the density is higher in the jet and the perturbation to normal flow caused by moving the NO injector close to the pinhole.

In the internal removal experiment, $\mathrm{OH}$ is not formed instantly at the pinhole but is built up linearly by $\mathrm{HO}_{2} / \mathrm{NO}$ conversion along the line from the pinhole to the laser axis. Therefore, the experimental internal removal may not be directly compared with the theoretical estimate. In such a sequential reaction system, the $\mathrm{OH}$ scavenging is about half as efficient as that for the case where $\mathrm{OH}$ is formed as an instant point source at the pinhole. Thus, the experimental value should be doubled to $(5.8 \pm 13) \%$, which is in reasonable agreement with the theoretical value. From this, we cannot rule out a small internal $\mathrm{OH}$ removal on the order of $10 \%$ at the higher propane level used for the AIRPRO summer campaign. However, no such corrections were applied to the ambient data featured in this work.

\subsection{Interference testing experiments}

\subsection{1 $\mathrm{O}_{3}+\mathrm{H}_{2} \mathrm{O}$ vapour}

In LIF-FAGE instruments, there is a known interference due to laser-generated $\mathrm{OH}$ from ozone photolysis in the presence of water vapour (Fuchs et al., 2016; Griffith et al., 2016; Tan et al., 2017). This interference was quantified by Whalley et al. (2018) and characterised in further detail in the present work. In these experiments, ozone was generated from the $184.9 \mathrm{~nm}$ photolysis of oxygen in a $12-20 \mathrm{slm}$ flow of zero air using a $\mathrm{Hg}(\mathrm{Ar})$ pen-ray lamp (LOT LSP035). Another 12-20 slm of zero air was humidified using a water (HPLCgrade) bubbler. The two zero air flows were combined and delivered to the calibration wand, from which the IPI sampled in a manner analogous to the experiments conducted to investigate external and internal $\mathrm{OH}$ removal discussed above. Ozone mixing ratios in the range $0-2.5 \mathrm{ppmv}$ were generated by varying the $\mathrm{Hg}$ lamp current $(0-21 \mathrm{~mA})$, while water vapour volume mixing ratios in the range $0.1 \%-1.0 \%$ were produced by varying the flow through the bubbler, or by bypassing it completely, and the total flow (32 slm) was compensated for by changing the dry zero air flow. Laser power (LP) at $308 \mathrm{~nm}$ was varied in the range $3-17 \mathrm{~mW}$ by varying the ratio of acetone: water in a cuvette placed before the fibre launcher that is used to send laser light to the detection cells.

Figure 7 shows the results of $\mathrm{O}_{3}+\mathrm{H}_{2} \mathrm{O}$ vapour interference tests. It can be seen that the interference signal $\left(\mathrm{OH}_{\text {int }}=\right.$ $\mathrm{OH}_{\text {wave }}-\mathrm{OH}_{\text {chem }}$ ) is linear in both ozone (Fig. 7a) and water vapour (Fig. 7b) mixing ratios. The quadratic dependence of the interference signal on laser power (Fig. 7c) in terms of raw count rates indicates that the interference originates from a two-photon process, as expected. However, since $\mathrm{OH}$ 
Table 2. Internal removal of $\mathrm{OH}(\%, \pm 2 \sigma)$ as a function of propane mixing ratio in the IPI flow tube, determined as shown in Fig. 6 (see text for details).

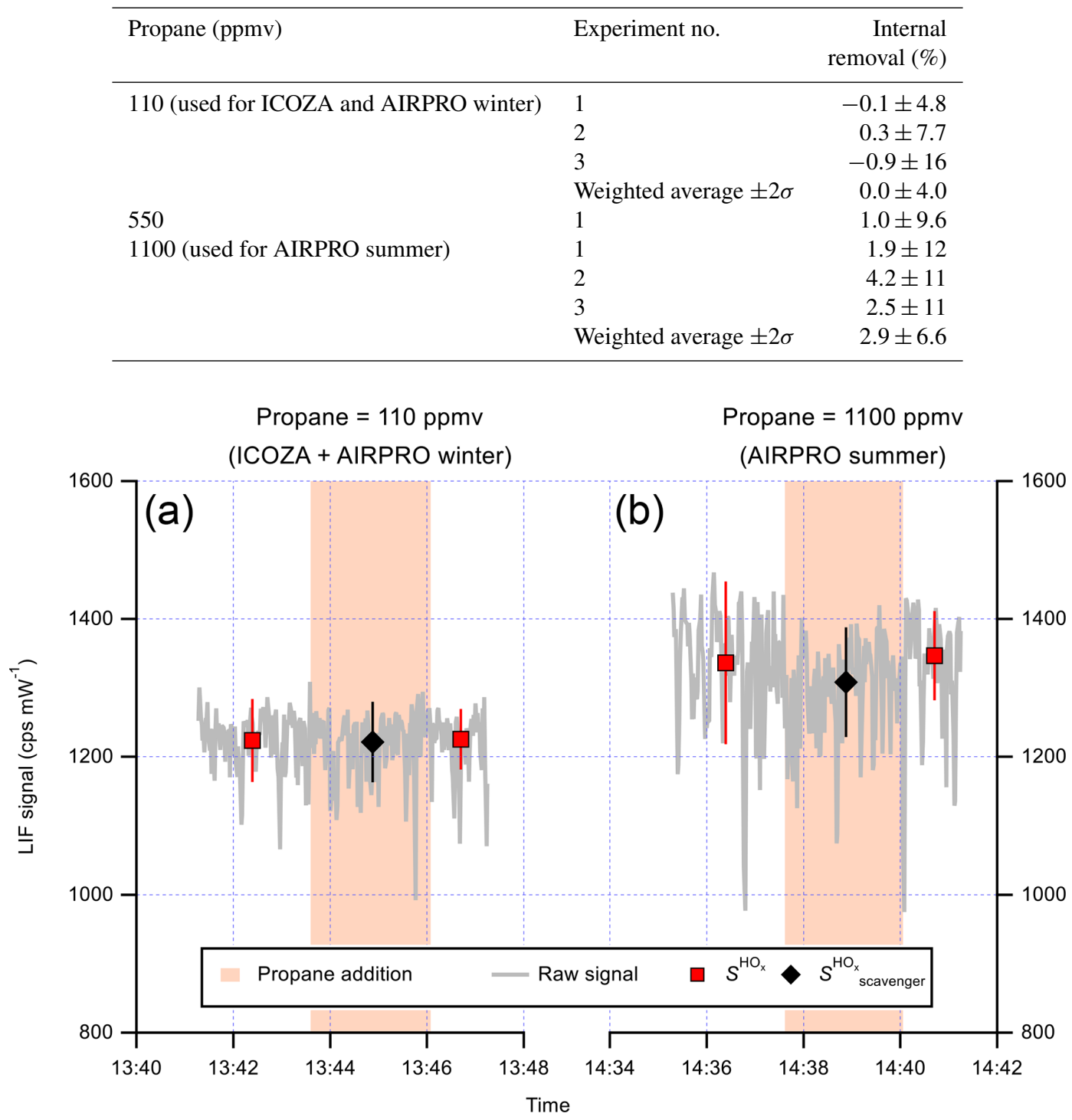

Figure 6. Time series of the LIF signal during internal $\mathrm{OH}$ removal experiments. The raw $1 \mathrm{~s}$ data are given by the grey line. NO was continuously added to the FAGE cell during these experiments (to form OH internally), and points where propane was added to the IPI flow tube are indicated by the orange-shaded panels, with the corresponding signal averages $( \pm 1 \sigma)$ shown as markers (see text for details). The first experiment (a) corresponds to the propane mixing ratio used for ICOZA, while the second (b) corresponds to that used for AIRPRO. The results of the internal $\mathrm{OH}$ removal experiments are summarised in Table 2.

data are normalised to laser power, the equivalent $\mathrm{OH}$ concentrations are linear with respect to laser power. Thus, overall, $\mathrm{OH}_{\text {int }}$ is linear in ozone, water vapour, and laser power. Normalisation of the slope in Fig. 7a yields the following relation:

$$
\begin{aligned}
{\left[\mathrm{OH}_{\text {int }}\right] } & =(565 \pm 42) \text { molec. } \mathrm{cm}^{-3} \mathrm{ppbv}^{-1} \%^{-1} \mathrm{~mW}^{-1} \\
& \times\left[\mathrm{O}_{3}\right] \times\left[\mathrm{H}_{2} \mathrm{O}\right] \times \mathrm{LP},
\end{aligned}
$$

where $\left[\mathrm{O}_{3}\right],\left[\mathrm{H}_{2} \mathrm{O}\right]$, and $\mathrm{LP}$ are in units of ppbv, \%, and $\mathrm{mW}$, respectively. Under typical atmospheric conditions of
$\left[\mathrm{O}_{3}\right]=50 \mathrm{ppbv}$ and $\left[\mathrm{H}_{2} \mathrm{O}\right]=1 \%$, and a typical instrument laser power of $15 \mathrm{~mW}$, the interference signal is equivalent to an $\mathrm{OH}$ concentration of $3.9 \times 10^{5}$ molec. $\mathrm{cm}^{-3}$. This signal is slightly smaller than the instrumental limit of detection (LOD) of $\sim 7 \times 10^{5}$ molec. $\mathrm{cm}^{-3}$ at a signal-to-noise ratio (SNR) of 2, but nonetheless it was used to correct the ambient $\mathrm{OH}_{\text {wave }}$ data presented in Sect. 3.3, using co-located measurements of ozone and water vapour. 
Table 3. Summary of interference tests with $\mathrm{O}_{3}$ and isoprene (ISO) in the presence of propane (PROP), based on the data in Fig. 8. n/a - not applicable.

\begin{tabular}{|c|c|c|c|c|c|c|c|c|}
\hline \multirow[t]{2}{*}{ Test } & \multirow{2}{*}{$\begin{array}{r}\mathrm{O}_{3} \\
(\mathrm{ppmv})\end{array}$} & \multirow{2}{*}{$\begin{array}{l}\mathrm{H}_{2} \mathrm{O} \\
(\%)\end{array}$} & \multirow{2}{*}{$\begin{array}{r}\text { ISO } \\
\text { (ppmv) }\end{array}$} & \multirow{2}{*}{$\begin{array}{l}\text { PROP } \\
\text { (ppmv) }\end{array}$} & \multicolumn{4}{|c|}{$\mathrm{OH}_{\text {int }}\left(\right.$ molec. $\left.\mathrm{cm}^{-3}\right)$} \\
\hline & & & & & Obs. & $\begin{array}{r}\text { Correction due to } \\
\mathrm{O}_{3}+\mathrm{H}_{2} \mathrm{O} \text { vapour } \\
\text { interference }^{\mathrm{a}}\end{array}$ & OP3 levels ${ }^{b}$ & AIRPRO 2017 levels $^{\mathrm{c}}$ \\
\hline A & 1.64 & 0.73 & 0 & 110 & $1.0 \times 10^{7}$ & 0 & $\mathrm{n} / \mathrm{a}$ & $\mathrm{n} / \mathrm{a}$ \\
\hline B & 1.86 & 0.07 & 16 & 110 & $1.9 \times 10^{7}$ & $1.8 \times 10^{7}$ & 21 & 430 \\
\hline $\mathrm{C}$ & 1.83 & 0.98 & 16 & 110 & $1.6 \times 10^{7}$ & $8.0 \times 10^{5}$ & 1 & 19 \\
\hline $\mathrm{D}$ & 1.85 & 0.07 & 16 & 1100 & $1.4 \times 10^{7}$ & $1.3 \times 10^{7}$ & 15 & 310 \\
\hline
\end{tabular}

${ }^{a}$ Corrected using Eq. (7). ${ }^{b}$ Oxidant and Particle photochemical processes field campaign in Borneo, 2008: average $\mathrm{O}_{3}=10$ ppbv; ISO $=3.5$ ppbv.

${ }^{c}$ Diurnally averaged maximum $\mathrm{O}_{3}=90$ ppbv; overall maximum ISO $=7.9 \mathrm{ppbv}$.

\subsubsection{Isoprene ozonolysis}

To test for interferences from isoprene (ISO) ozonolysis products, isoprene $(\sim 16 \mathrm{ppmv})$, and ozone $(\sim 1.8 \mathrm{ppmv})$ were mixed in the calibration wand and the scavenger (propane, PROP) was injected into the IPI flow tube. The propane concentrations were set to those used for ambient $\mathrm{OH}_{\text {chem }}$ measurements, such that the tests were representative of normal atmospheric sampling (i.e. to test whether an interference signal would remain in ambient data). However, to generate sufficient $\mathrm{OH}$ signal for quantitative analysis, ozone and isoprene were introduced at concentrations that far exceeded their typical ambient levels (Table 3). Unlike previous tests of interferences from alkene ozonolysis (Novelli et al., 2014b), low [O $\mathrm{O}_{3}$ ] : [ISO] ratios were used to suppress the signal contribution from the atmospheric (real) OH generated by ozonolysis (i.e. isoprene acted as an additional $\mathrm{OH}$ scavenger). To allow sufficient time for steady-state conditions to develop, the IPI did not sample from the calibration wand directly, but instead a $30 \mathrm{~cm}$ flow tube (polycarbonate, ID $\sim 19 \mathrm{~mm}$ ) was used to extend the IPI (which sampled wand gas at the normal IPI flow rate of $\sim 32 \mathrm{slm}$, residence time for $\mathrm{O}_{3}+$ isoprene reaction $\sim 0.15 \mathrm{~s}$ ).

Time series of the interference testing experiments conducted using the IPI are shown in Fig. 8. In Fig. 8a, no isoprene is added, but due to ozone photolysis in the presence of high $\left[\mathrm{H}_{2} \mathrm{O}\right](0.73 \%)$ an interference signal $\left(\mathrm{OH}_{\text {int }}\right)$ is observed (i.e. signal in the presence of propane is higher than the offline signal). The magnitude of this signal $\left(\mathrm{OH}_{\text {int }}\right.$ $\sim 1.0 \times 10^{7}$ molec. $\mathrm{cm}^{-3}$ ) yields a scale factor of $510 \pm$ 270 molec. $\mathrm{cm}^{-3} \mathrm{ppbv}^{-1} \%^{-1} \mathrm{~mW}^{-1}$ when linearly extrapolated down from the measured $\left[\mathrm{O}_{3}\right],\left[\mathrm{H}_{2} \mathrm{O}\right]$, and $\mathrm{LP}$, in agreement with the $565 \pm 42$ molec. $\mathrm{cm}^{-3} \mathrm{ppbv}^{-1} \%^{-1} \mathrm{~mW}^{-1}$ in Eq. (7).

In Fig. 8b, ozone and isoprene react under dry conditions, and an interference signal is observed again. The low $\mathrm{H}_{2} \mathrm{O}(0.07 \%)$ suppressed the $\mathrm{O}_{3}+\mathrm{H}_{2} \mathrm{O}$ interference, such that this cannot explain the magnitude of $\mathrm{OH}_{\text {int }}(\sim 1.9 \times$ $10^{7}$ molec. $\mathrm{cm}^{-3}$, Table 3 ), suggesting that $\mathrm{OH}$ was formed internally from a reaction other than $\mathrm{O}^{1} \mathrm{D}+\mathrm{H}_{2} \mathrm{O}$. Under high-humidity $\left(\mathrm{H}_{2} \mathrm{O} \sim 1 \%\right)$ conditions (Fig. 8c), $\mathrm{OH}_{\text {int }}(\sim$ $1.6 \times 10^{7}$ molec. $\mathrm{cm}^{-3}$ ) was similar, but in this case the signal can be explained almost entirely by the $\mathrm{O}_{3}+\mathrm{H}_{2} \mathrm{O}$ interference. Under dry conditions with a 10 -fold higher concentration of propane (as used for the AIRPRO summer campaign, Fig. 8c), the interference signal from Fig. 8b was reduced but remained elevated relative to the offline signal $\left(\mathrm{OH}_{\text {int }}\right.$ $\sim 1.4 \times 10^{7}$ molec. $\mathrm{cm}^{-3}$ ), where again the contribution from $\mathrm{O}_{3}+\mathrm{H}_{2} \mathrm{O}$ cannot explain the discrepancy. The decrease in $\mathrm{OH}_{\text {int }}$ between Fig. $8 \mathrm{~b}$ and d may be attributed to the suppression of steady-state $\mathrm{OH}$ generated from ozonolysis, but the remaining signal implies that $\mathrm{OH}$ was also formed internally in both cases. For the dry, low-propane experiment (Fig. 8b), the magnitude of the $\mathrm{OH}$ signal is much higher than that calculated from a steady-state model $\left(\sim 1.4 \times 10^{6}\right.$ molec. $\left.\mathrm{cm}^{-3}\right)$.

The suppression of the interference signal attributable to $\mathrm{O}_{3}$ /isoprene only (i.e. $\mathrm{O}_{3}+\mathrm{H}_{2} \mathrm{O}$ corrected) by the addition of water vapour $\left(\mathrm{H}_{2} \mathrm{O} \sim 1 \%\right.$; see Fig. 8c) suggests that the internal $\mathrm{OH}$ may have been formed from SCIs. The simplest $\mathrm{C} 1$ and $\mathrm{C} 2 \mathrm{SCIs}$ are known to react quickly with the water vapour dimer $\left(k \sim 4-7 \times 10^{-12} \mathrm{~cm}^{3}\right.$ molec. $^{-1} \mathrm{~s}^{-1}$ at $298 \mathrm{~K}$ for $\mathrm{CH}_{2} \mathrm{OO}$; Chao et al., 2015; Lewis et al., 2015) and monomer $\left(k \sim 1-2 \times 10^{-14} \mathrm{~cm}^{3}\right.$ molec $^{-1} \mathrm{~s}^{-1}$ for anti$\mathrm{CH}_{3} \mathrm{CHOO}$; Taatjes et al., 2013; Sheps et al., 2014; Lin et al., 2016), respectively. Reaction with the water vapour monomer was also shown to be relatively fast $(k \sim 1.2 \times$ $10^{-15} \mathrm{~cm}^{3}$ molec. ${ }^{-1} \mathrm{~s}^{-1}, k_{\text {loss }} \sim 300 \mathrm{~s}^{-1}$ at $\sim 1 \% \mathrm{H}_{2} \mathrm{O}$ ) for the ensemble of SCIs, including the $\mathrm{C} 1 \mathrm{SCI}$, generated from isoprene ozonolysis (Newland et al., 2015).

However, regardless of whether the signal observed at high propane is due to internally formed $\mathrm{OH}$, which may have originated from SCIs, the equivalent $\mathrm{OH}$ concentrations are negligible when extrapolated back to ambient chemical conditions (Table 3). Assuming a linear dependence of the interference signal on both ozone and isoprene, the interference (after $\mathrm{O}_{3}+\mathrm{H}_{2} \mathrm{O}$ correction) is equivalent to $<10^{2}$ molec. $\mathrm{cm}^{-3}$ at the ozone (10 ppbv) and isoprene (3.5 ppbv) levels measured in a low- $\mathrm{NO}_{x}$, biogenic environ- 

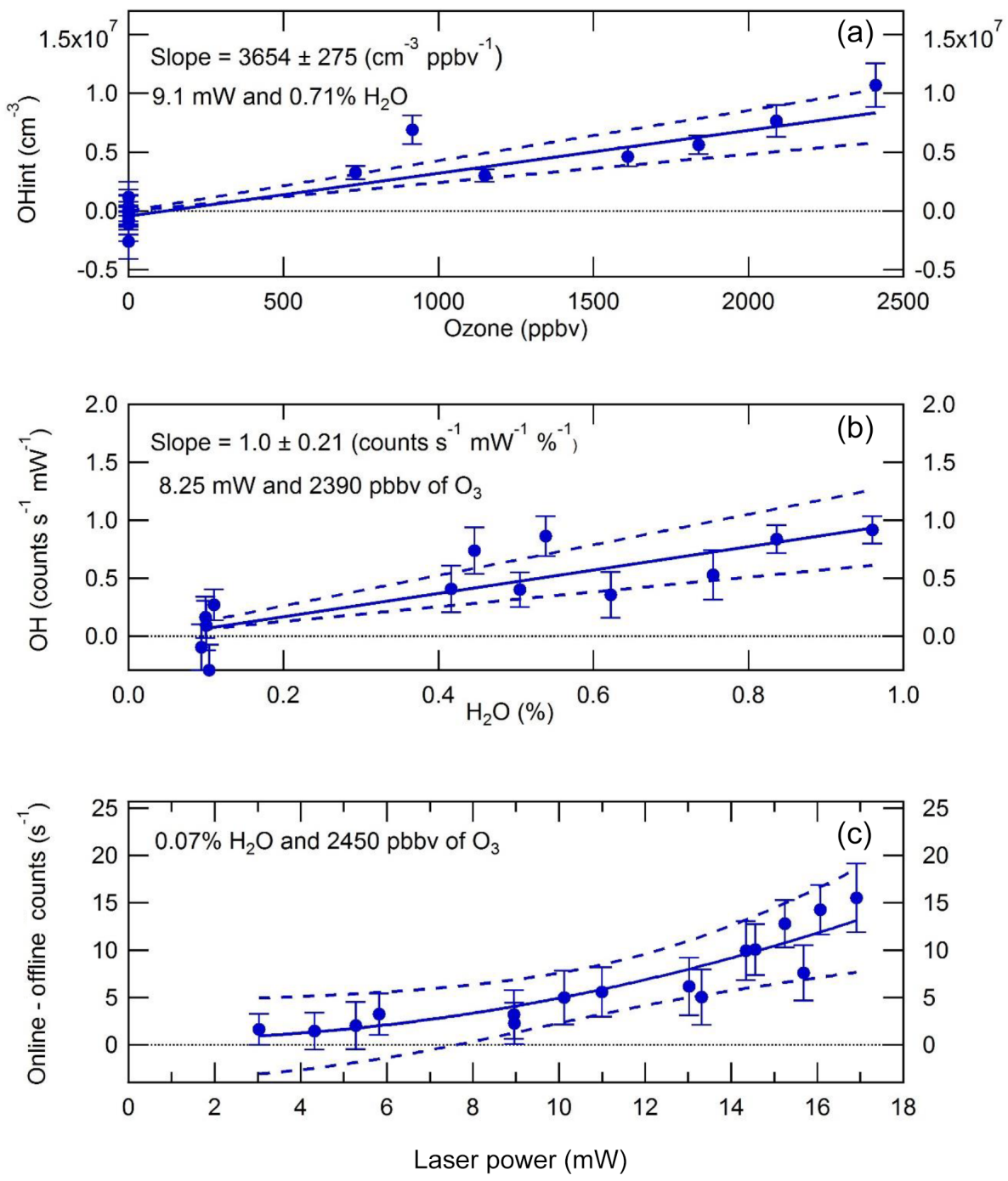

Figure 7. $\mathrm{OH}$ interference $( \pm 1 \sigma)$ from $\mathrm{O}_{3}+\mathrm{H}_{2} \mathrm{O}$ as a function of (a) $\mathrm{O}_{3}$, (b) $\mathrm{H}_{2} \mathrm{O}$, and (c) laser power. The interference signal is linear in $\mathrm{O}_{3}$ and $\mathrm{H}_{2} \mathrm{O}$ mixing ratios and quadratic in laser power, confirming the two-photon nature of the process. Normalising the slope in panel (a) to $\mathrm{O}_{3}=1 \mathrm{ppbv}, \mathrm{H}_{2} \mathrm{O}=1 \%$, and laser power $=1 \mathrm{~mW}$ yields an $\mathrm{OH}$ interference equivalent to a concentration of $565 \pm 42 \mathrm{molec}$. $\mathrm{cm}^{-3}$.

ment during the Oxidants and Particle photochemical processes (OP3) campaign in Borneo, 2008 (Hewitt et al., 2010). Similarly, we have modelled the SCI decomposition in our FAGE cell. We assumed an ambient atmosphere containing $100 \mathrm{ppbv} \mathrm{O}_{3}$ and $10 \mathrm{ppbv}$ trans-2-butene and took the reactions, rate coefficients, and yields from Novelli et al. (2014a) and MCMv3.3.1. The rate of CI to SCI was $1 \times 10^{6} \mathrm{~s}^{-1}$ with an SCI yield of 0.18. The unimolecular decomposition of SCI to $\mathrm{OH}$ was $3 \mathrm{~s}^{-1}$ and the wall loss rate of SCI was $22 \mathrm{~s}^{-1}$. From this we calculate an equivalent ambient pressure $\mathrm{OH}$ concentration of $\sim 4 \times 10^{3}$ molec. $\mathrm{cm}^{-3}$ from the decomposition of SCIs at our FAGE cell residence time of $2 \mathrm{~ms}$. The insignificance of the interference signal for atmospherically relevant $\mathrm{O}_{3} /$ alkene concentrations is consistent with the results of previous interference experiments, for which equivalent $\mathrm{OH}$ concentrations of $\sim 3-4 \times 10^{4}$ (Novelli et al., 2014b;
Fuchs et al., 2016) and $\sim 4 \times 10^{5}$ molec. $\mathrm{cm}^{-3}$ (Rickly and Stevens, 2018) can be derived.

\subsection{3 $\mathrm{NO}_{3}$ radicals}

Fuchs et al. (2016) found that, despite the absence of a hydrogen atom, $\mathrm{NO}_{3}$ radicals were responsible for a small $\mathrm{OH}$ interference signal in the Forschungszentrum Jülich (FZJ) LIF-FAGE instrument, equivalent to an $\mathrm{OH}$ concentration of $1.1 \times 10^{5}$ molec. $\mathrm{cm}^{-3}$ per 10 pptv $\mathrm{NO}_{3}$. The $\mathrm{OH}$ interference scaled linearly with observed $\mathrm{NO}_{3}$ mixing ratios but showed no dependence on inlet length, cell pressure, laser power, or humidity, and the background signal did not change significantly in the presence of $\mathrm{CO}$ scavenger, suggesting the $\mathrm{OH}$ was indeed being formed internally. It was postulated that the interference was a result of a heterogeneous process involv- 

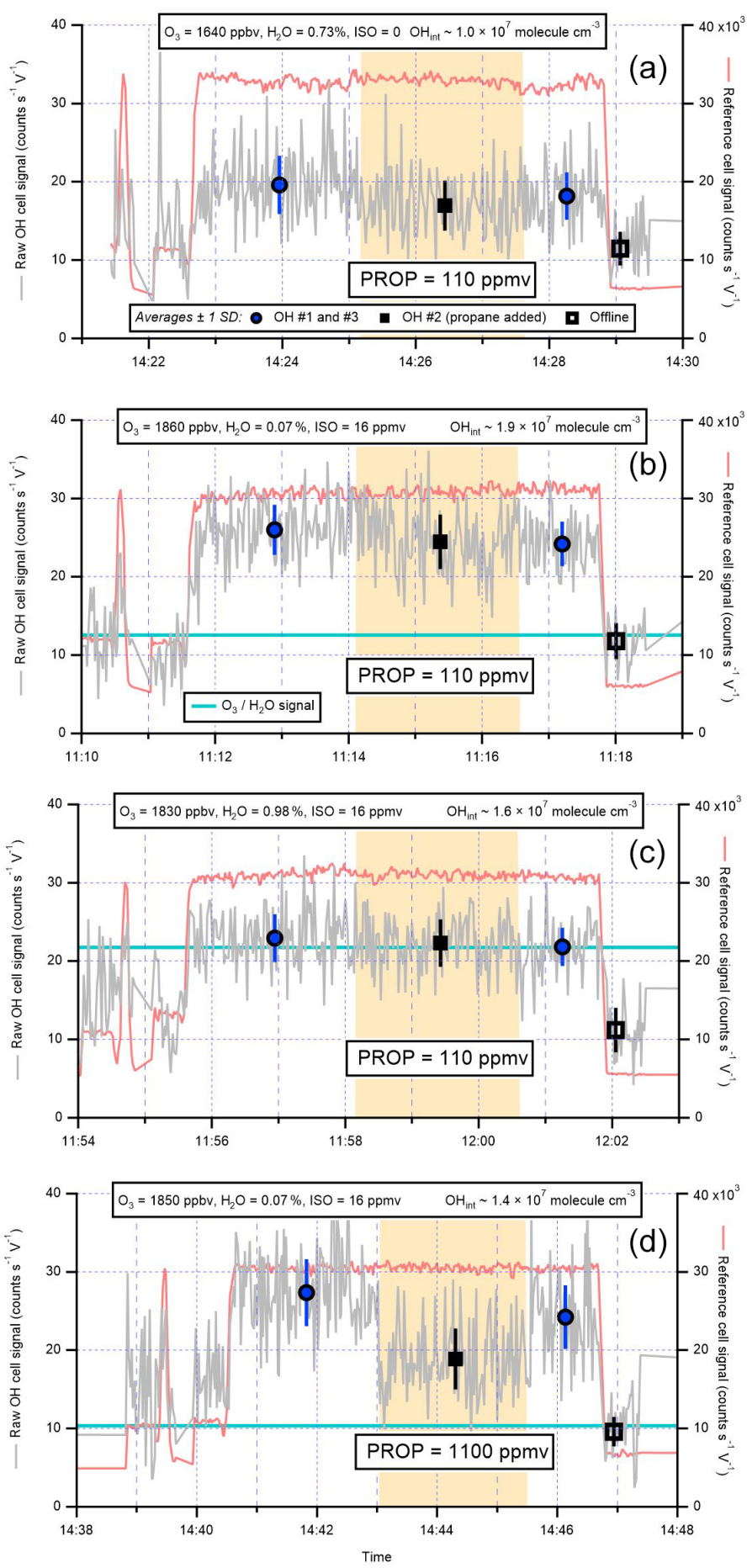

Figure 8. Isoprene (ISO) ozonolysis interference tests: (a) $\mathrm{O}_{3} / \mathrm{H}_{2} \mathrm{O}$ only, (b) $\mathrm{O}_{3}$ and ISO under dry conditions, (c) $\mathrm{O}_{3}$ and isoprene with $\mathrm{H}_{2} \mathrm{O}$ added, and (d) $\mathrm{O}_{3}$ and isoprene under dry conditions but with a higher concentration of propane (PROP) to remove any steady-stategenerated $\mathrm{OH}$. Shaded areas are periods of propane addition, and the light blue lines correspond to the calculated signals from $\mathrm{O}_{3}+\mathrm{H}_{2} \mathrm{O}$ only (for experiments with isoprene present). The interference signals ("OH no. 2" - "offline") were used to derive equivalent OH concentrations $\left(\mathrm{OH}_{\mathrm{int}}\right)$, which are on the order of $\sim 1-2 \times 10^{7}$ molec. $\mathrm{cm}^{-3}$. These experiments are summarised in Table 3 . See text for further details. 


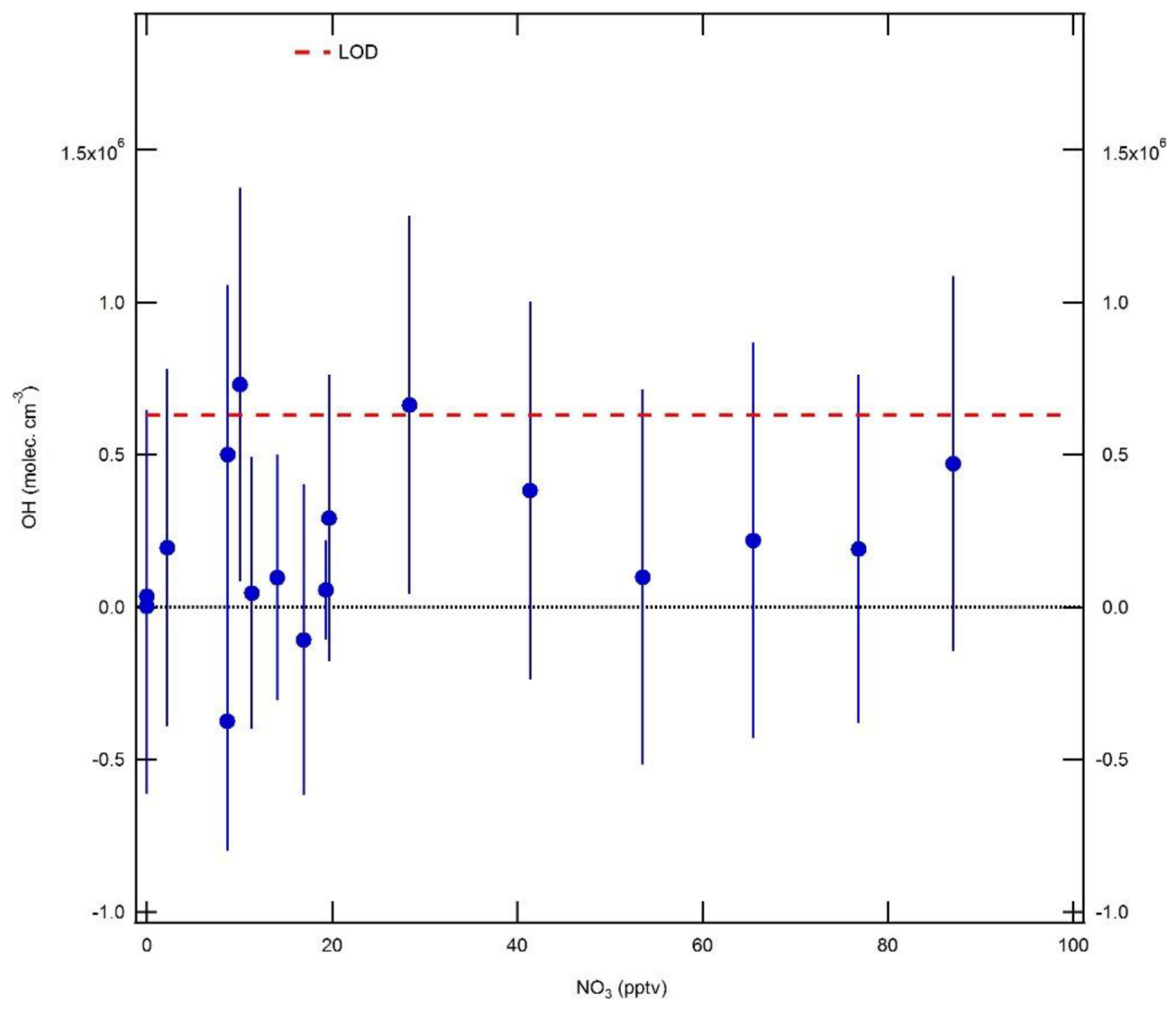

Figure 9. Equivalent $\mathrm{OH}$ concentrations $( \pm 1 \sigma)$ measured during $\mathrm{NO}_{3}$ radical interference tests. $\mathrm{NO}_{3}$ concentrations were calculated using a box model, and $\mathrm{OH}$ interference signals were corrected for the interference from $\mathrm{O}_{3}+\mathrm{H}_{2} \mathrm{O}$. The $\mathrm{OH}$ limit of detection (LOD, $6.3 \times$ $10^{5}$ molec. $\mathrm{cm}^{-3}, \mathrm{SNR}=2$ ) is denoted by the dashed red line.

ing $\mathrm{NO}_{3}$ and $\mathrm{H}_{2} \mathrm{O}$ adsorbed on instrument walls. Interference signals were also observed in the detection of $\mathrm{HO}_{2}$ and $\mathrm{RO}_{2}$ radicals, equivalent to $1.0 \times 10^{7}$ and $1.7 \times 10^{7}$ molec. $\mathrm{cm}^{-3}$, respectively, per 10 pptv $\mathrm{NO}_{3}$.

To test for an $\mathrm{NO}_{3}$ interference in $\mathrm{OH}$ measurements made by the Leeds FAGE instrument, $\mathrm{NO}_{3}$ was generated from the reaction of ozone and $\mathrm{NO}_{2}$ :

$\mathrm{O}_{3}+\mathrm{NO}_{2} \rightarrow \mathrm{NO}_{3}$,

$\mathrm{NO}_{3}+\mathrm{NO}_{2} \rightarrow \mathrm{N}_{2} \mathrm{O}_{5}$,

$\mathrm{N}_{2} \mathrm{O}_{5} \rightarrow \mathrm{NO}_{3}+\mathrm{NO}_{2}$.

In these experiments, ozone was generated by flowing zero air $(15 \mathrm{slm})$ past a Hg lamp (LOT LSP035). A constant $0.5 \mathrm{slm}$ flow of $\mathrm{NO}_{2}$ (BOC, $2 \mathrm{ppmv}$ ) was diluted in $25 \mathrm{slm}$ zero air and mixed with the zero air-ozone flow and an additional zero air dilution flow of $10 \mathrm{slm}$, in order to yield a final mixing ratio of $20 \mathrm{ppbv}$. Gas was delivered to the IPI system using the calibration wand, with a total residence time of $3.7 \mathrm{~s}$ for the $\mathrm{O}_{3}+\mathrm{NO}_{2}$ reaction. Ozone mixing ratios in the range $0-2.8 \mathrm{ppmv}$ (after dilution) were generated by varying the current supplied to the Hg lamp. $\mathrm{NO}_{3}$ radical mixing ratios in the range $0-90$ pptv were cal- culated based on a box model with rate constants taken from the Master Chemical Mechanism (MCM; http://mcm. leeds.ac.uk/MCM, last access: 15 December 2017) version 3.3.1 $\left(k_{R 1}=3.52 \times 10^{-17} \mathrm{~cm}^{3}\right.$ molec. $^{-1} \mathrm{~s}^{-1}, k_{R 2}=1.24 \times$ $10^{-12} \mathrm{~cm}^{3}$ molec. ${ }^{-1} \mathrm{~s}^{-1}$, and $k_{R 3}=0.045 \mathrm{~s}^{-1}$ ). These experiments were performed under dry conditions $\left(\mathrm{H}_{2} \mathrm{O} \sim\right.$ $0.07 \%$ ), such that only a small correction was applied for the $\mathrm{O}_{3} / \mathrm{H}_{2} \mathrm{O}$ interference.

The results of the $\mathrm{NO}_{3}$ radical interference tests are shown in Fig. 9. It can be seen that the equivalent $\mathrm{OH}$ signals were all $<8 \times 10^{5}$ molec. $\mathrm{cm}^{-3}$ and almost always below the instrument LOD of $6.3 \times 10^{5}$ molec. $\mathrm{cm}^{-3}(\mathrm{SNR}=2)$. Unlike the dependence found by Fuchs et al. (2016), the interference signal does not increase linearly with $\mathrm{NO}_{3}$. However, based on the point at the highest $\mathrm{NO}_{3}$ mixing ratio of $\sim 90$ pptv, the interference is equivalent to an insignificant $\sim 6 \times 10^{4}$ molec. $\mathrm{cm}^{-3}$ at 10 pptv $\mathrm{NO}_{3}$, or approximately half of that observed by Fuchs et al. (2016). These experiments suggest that an interference from $\mathrm{NO}_{3}$ radicals is not significant for the detection of $\mathrm{OH}$ using the Leeds ground-based FAGE instrument. 


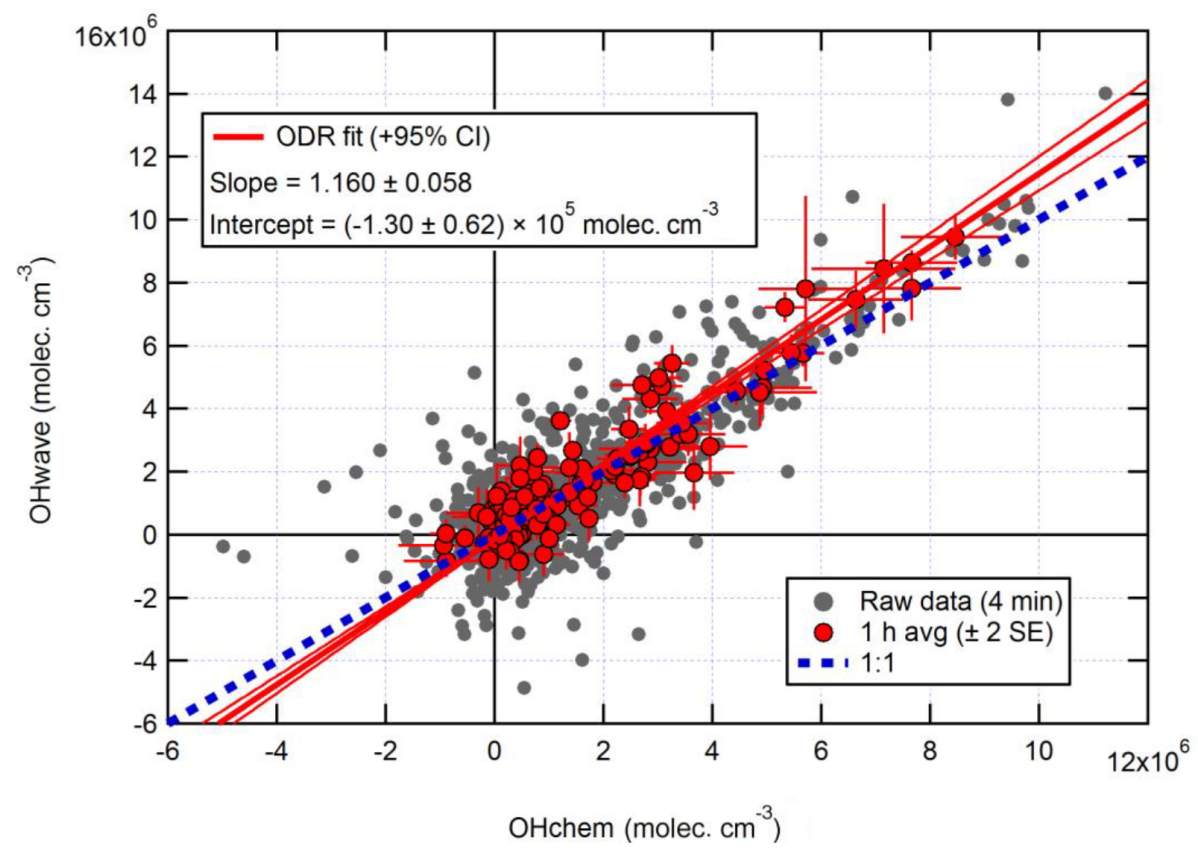

Figure 10. Overall intercomparison of $\mathrm{OH}_{\text {wave }}$ and $\mathrm{OH}_{\text {chem }}$ observations from the ICOZA campaign. Grey markers represent raw data (4 min), with $1 \mathrm{~h}$ averages ( \pm 2 standard error, SE) in red. The thick red line is the orthogonal distance regression (ODR) fit to the hourly data, with its $95 \%$ confidence interval (CI) bands given by the thin red lines; fit errors are given at the $2 \sigma$ level. For comparison, $1: 1$ agreement is denoted by the dashed blue line. $\mathrm{OH}_{\text {wave }}$ data were corrected for the known interference from $\mathrm{O}_{3}+\mathrm{H}_{2} \mathrm{O}$.

\subsection{Ambient observations of $\mathrm{OH}_{\text {wave }}$ and $\mathrm{OH}_{\text {chem }}$}

\subsubsection{ICOZA 2015}

Figure 10 shows the overall intercomparison of $\mathrm{OH}_{\text {wave }}$ (with $\mathrm{O}_{3}+\mathrm{H}_{2} \mathrm{O}$ interference as given in Eq. 7 subtracted) and $\mathrm{OH}_{\text {chem }}$ measurements made during the ICOZA 2015 campaign. It is evident that the raw data (averaged for 4 min periods) are quite noisy, but averaging to $1 \mathrm{~h}$ improves the precision and reveals a tight correlation, with the majority of points scattered around the line of $1: 1$ agreement. An orthogonal distance regression (ODR) fit (Boggs et al., 1987), which accounts for errors in both the $y$ and $x$ directions, to the hourly data yields a slope of $1.160 \pm 0.058(2 \sigma)$ and a negative intercept on the order of the instrumental precision. In a similar manner, an unweighted least-squares linear fit (not shown) gives a slope of $1.060 \pm 0.065$, an intercept of $(0.5 \pm 1.5) \times 10^{5}$ molec. $\mathrm{cm}^{-3}$, and a correlation coefficient $\left(R^{2}\right)$ of 0.992 . Regardless of the fit method, these results show that, on average, the two $\mathrm{OH}$ measurements agree within the instrumental uncertainty of $\sim 26 \%$ at $2 \sigma$.

Median hourly diurnal profiles of $\mathrm{OH}_{\text {wave }}, \mathrm{OH}_{\text {chem }}$, and $J\left(\mathrm{O}^{1} \mathrm{D}\right)$, averaged over both IPI sampling periods, are shown in Fig. 11. The two $\mathrm{OH}$ measurements exhibit virtually identical profiles, with peak values of $\sim 3 \times 10^{6}$ molec. $\mathrm{cm}^{-3}$ slightly before solar noon, and relatively high concentrations $\left(\sim 1-2 \times 10^{6}\right.$ molec. $\left.\mathrm{cm}^{-3}\right)$ persisting into the early evening despite the concomitant falloff in $J\left(\mathrm{O}^{1} \mathrm{D}\right)$. Night-time levels were generally below $5 \times 10^{5}$ molec. $\mathrm{cm}^{-3}$. The variability in $\mathrm{OH}$ concentrations, shown only for $\mathrm{OH}_{\text {chem }}$ for clarity, was high during both daytime and night-time periods.

In Fig. 10 it can be seen that some points lie substantially above the 1:1 line, especially for the 4 min averaged raw data. It is possible that, despite the good overall agreement between the median diurnal profiles of $\mathrm{OH}_{\text {wave }}$ and $\mathrm{OH}_{\text {chem }}$ in Fig. $11, \mathrm{OH}_{\text {int }}$ may have exhibited its own distinct diurnal profile, independent of atmospheric $\mathrm{OH}$ concentrations, for example if the interference signal was generated from a particular chemical species. However, the median diurnal profile of individual $\mathrm{OH}_{\text {int }}$ measurements $\left(=\mathrm{OH}_{\text {wave }}-\right.$ $\mathrm{OH}_{\text {chem }}$ ) in Fig. 11 exhibits no obvious structure, with values scattered around zero and a mean $\pm 2 \sigma$ value of $(0.3 \pm 3.3)$ $\times 10^{5}$ molec. $\mathrm{cm}^{-3}$, which is well below the LOD for individual $\mathrm{OH}$ measurements. Similarly, the average $\left(\mathrm{OH}_{\text {wave }}-\right.$ $\mathrm{OH}_{\text {chem }}$ ) $/ \mathrm{OH}_{\text {wave }}$ ratio (i.e. the contribution of interferences to the total $\mathrm{OH}_{\text {wave }}$ signal) was zero within error (mean \pm 2 standard error, $\mathrm{SE},=0.03 \pm 0.12$ ).

Furthermore, $\mathrm{OH}_{\text {int }}$ does not exhibit any dependence when binned against various parameters (Fig. S1 in the Supplement), including those previously implicated in LIF-FAGE measurement interferences, such as $J\left(\mathrm{O}^{1} \mathrm{D}\right)$ (Feiner et al., 2016); temperature (Mao et al., 2012; Novelli et al., 2017); $\mathrm{OH}$ reactivity (Mao et al., 2012); and $\mathrm{O}_{3}$ (Feiner et al., 2016; Novelli et al., 2017), isoprene (Feiner et al., 2016), and NO (Feiner et al., 2016) mixing ratios. 


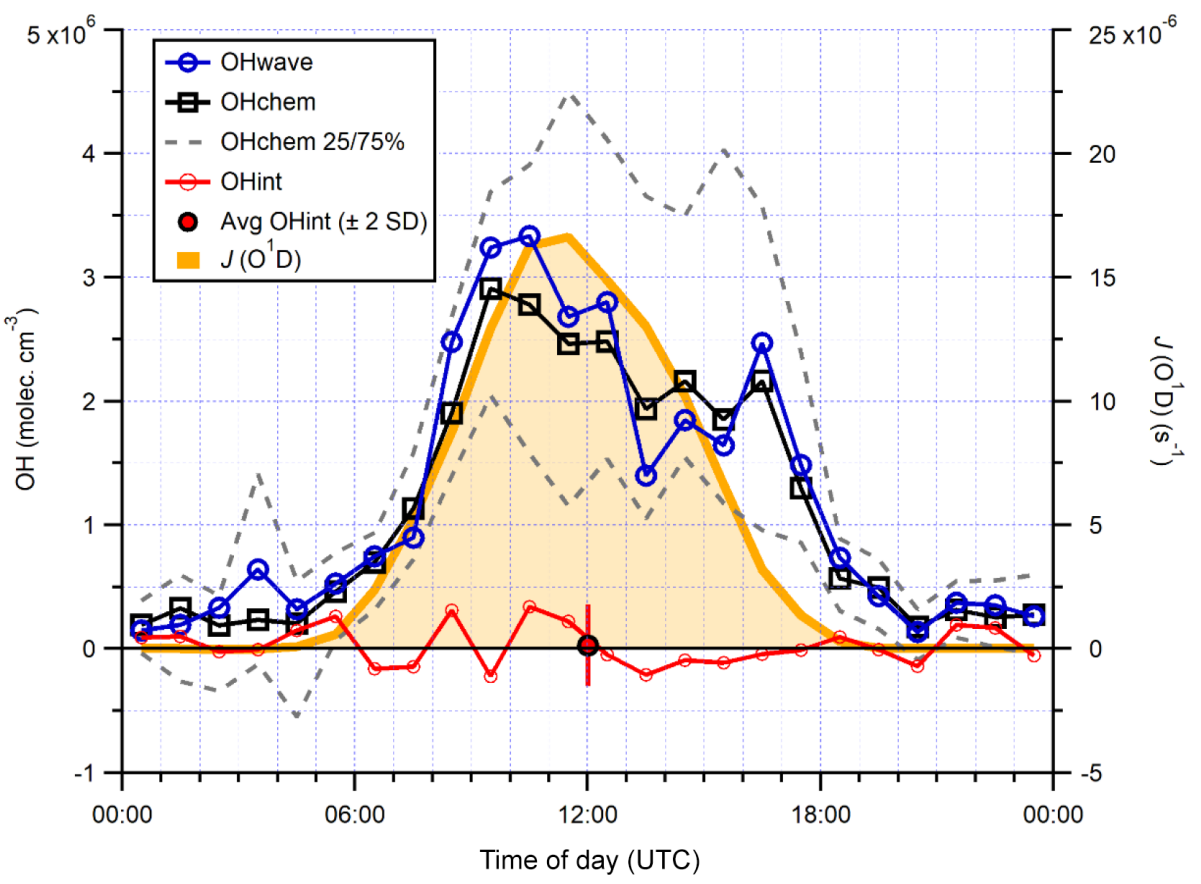

Figure 11. Hourly median diurnal profiles of $\mathrm{OH}_{\mathrm{wave}}, \mathrm{OH}_{\mathrm{chem}}$, and $J\left(\mathrm{O}^{1} \mathrm{D}\right)$ (right axis) from the ICOZA campaign. Also shown (red line and markers) is the hourly median diurnal profile of $\mathrm{OH}_{\mathrm{int}}\left(=\mathrm{OH}_{\mathrm{wave}}-\mathrm{OH}_{\mathrm{chem}}\right)$, calculated from individual 4 min data points; the single red marker corresponds to the average $( \pm 2 \sigma)$ of this trace. The variability (interquartile range, IQR) in $\mathrm{OH}_{\text {chem }}$ measurements is denoted by the dashed grey lines and is not shown for others for clarity. $\mathrm{OH}_{\text {wave }}$ data were corrected for the known interference from $\mathrm{O}_{3}+\mathrm{H}_{2} \mathrm{O}$.

\subsubsection{AIRPRO winter 2016}

The overall agreement between the two measurements is presented in the correlation plot in Fig. 12. As with ICOZA (Fig. 10), a tight correlation is revealed after averaging the data to $1 \mathrm{~h}$, and all points are distributed evenly around the line of $1: 1$ agreement. ODR fitting yields an overall slope of $1.051 \pm 0.039$ and a negative intercept of a similar magnitude to the instrumental precision. An unweighted leastsquares linear fit (not shown) gives a slope of $0.997 \pm 0.038$, an intercept of $(5.1 \pm 7.3) \times 10^{4}$ molec. $\mathrm{cm}^{-3}$, and an $R^{2}$ of 0.97 .

The two measurements exhibit the same profile on a diurnal basis (Fig. 13), with a diel maximum of $\sim 3 \times$ $10^{6}$ molec. $\mathrm{cm}^{-3}$ occurring in the late morning due to the build-up of HONO overnight. At night, $\mathrm{OH}_{\text {chem }}$ concentrations were close to the LOD $\left(<\sim 2 \times 10^{5}\right.$ molec. $\left.\mathrm{cm}^{-3}\right)$, while $\mathrm{OH}_{\text {wave }}$ measurements were frequently negative, possibly as a result of over-subtraction of the $\mathrm{O}_{3} / \mathrm{H}_{2} \mathrm{O}$ interference as this is subject to high uncertainty (Fig. 7). The diurnal profile of $\mathrm{OH}_{\text {int }}$ is scattered around zero with a mean $\pm 2 \sigma$ difference of $(-0.9 \pm 2.7) \times 10^{5}$ molec. $\mathrm{cm}^{-3}$, and the mean $\pm 2 \mathrm{SE}$ contribution of interferences to the total signal was $-0.02 \pm 0.07$.

\subsubsection{AIRPRO summer 2017}

The intercomparison of $\mathrm{OH}_{\text {wave }}$ and $\mathrm{OH}_{\text {chem }}$ measurements for the AIRPRO summer campaign is shown in Fig. 14. Consistent with ICOZA and the AIRPRO winter results, the $1 \mathrm{~h}$ data are scattered around the $1: 1$ line, with an overall ODR slope of $1.103 \pm 0.017$. However, the intercept is more negative than for the other campaigns, which suggests that the $\mathrm{O}_{3} / \mathrm{H}_{2} \mathrm{O}$ interference may have been overestimated because it is during this campaign that the highest ozone mixing ratios ( $\sim 90$ ppbv diurnally averaged maximum, Table 1$)$ were encountered. Similarly, an unweighted least-squares linear fit to the data (not shown) yields a slope of $1.111 \pm 0.029$, an intercept of $(-3.8 \pm 1.7) \times 10^{5}$ molec. $\mathrm{cm}^{-3}$, and an $R^{2}$ of 0.92 (data not shown).

Again, the two measurements follow the same diurnal profile (Fig. 15), peaking in the afternoon at $\sim 1 \times$ $10^{7}$ molec. $\mathrm{cm}^{-3}$ with relatively high night-time levels of $\sim 1-2 \times 10^{6}$ molec. $\mathrm{cm}^{-3}$. As with ICOZA and the AIRPRO winter campaign, the $\mathrm{OH}_{\text {int }}$ diurnal profile does not exhibit any obvious structure, with values scattered around zero and a mean $\pm 2 \sigma$ difference of $(-1.6 \pm 4.1) \times 10^{5}$ molec. $\mathrm{cm}^{-3}$. The mean $\pm 2 \mathrm{SE}\left(\mathrm{OH}_{\text {wave }}-\mathrm{OH}_{\text {chem }}\right) / \mathrm{OH}_{\text {wave }}$ ratio was $-0.09 \pm 0.10$. During AIRPRO, measured $\mathrm{NO}_{3}$ mixing ratios reached up to $\sim 100 \mathrm{pptv}$, such that the lack of significant night-time $\mathrm{OH}$ interference signals is consistent with the results of $\mathrm{NO}_{3}$ interference tests (Sect. 3.2.3). 


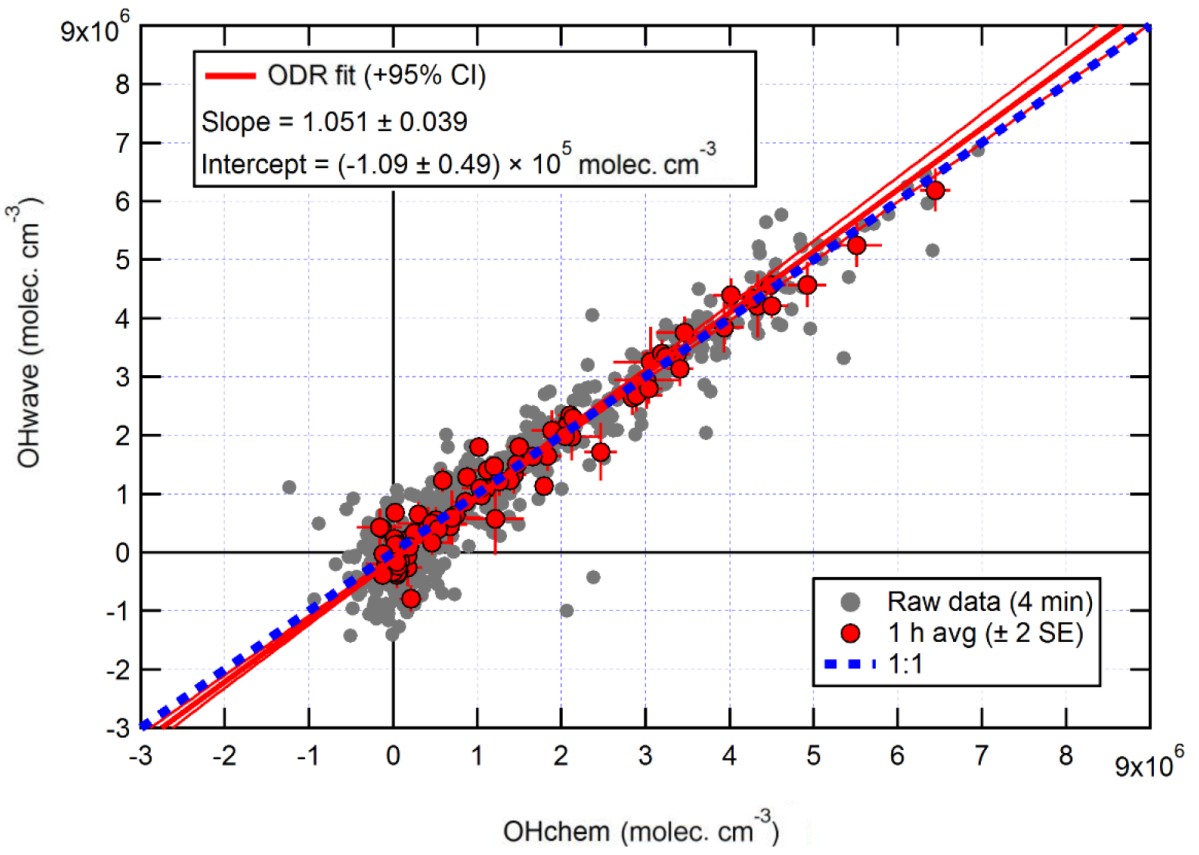

Figure 12. Overall intercomparison of $\mathrm{OH}_{\text {wave }}$ and $\mathrm{OH}_{\text {chem }}$ observations from the winter 2016 AIRPRO campaign. Grey markers represent raw data (4 min), with $1 \mathrm{~h}$ averages ( $\pm 2 \mathrm{SE}$ ) in red. The thick red line is the ODR fit to the hourly data, with its $95 \%$ CI bands given by the thin red lines; fit errors are given at the $2 \sigma$ level. For comparison, $1: 1$ agreement is denoted by the dashed blue line. $\mathrm{OH}_{\mathrm{wave}} \mathrm{data}_{\mathrm{were}}$ corrected for the known interference from $\mathrm{O}_{3}+\mathrm{H}_{2} \mathrm{O}$.

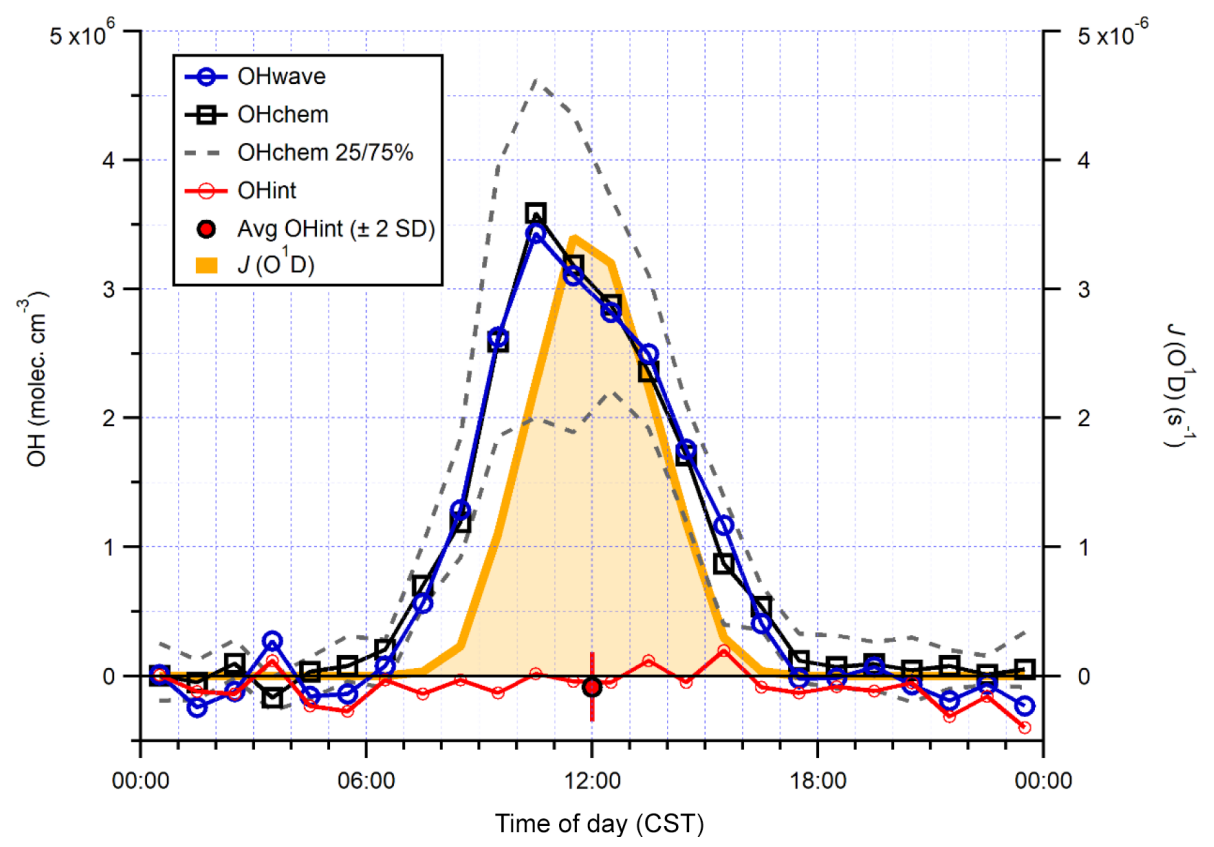

Figure 13. Hourly median diurnal profiles of $\mathrm{OH}_{\text {wave }}, \mathrm{OH}_{\mathrm{chem}}$, and $J\left(\mathrm{O}^{1} \mathrm{D}\right)$ (right axis) from the winter 2016 AIRPRO campaign. Also shown (red line and markers) is the hourly median diurnal profile of $\mathrm{OH}_{\text {int }}$, calculated from individual 4 min data points; the single red marker corresponds to the average $( \pm 2 \sigma)$ of this trace. The variability (IQR) in $\mathrm{OH}_{\text {chem }}$ measurements is denoted by the dashed grey lines and is not shown for others for clarity. $\mathrm{OH}_{\text {wave }}$ data were corrected for the known interference from $\mathrm{O}_{3}+\mathrm{H}_{2} \mathrm{O}$. 


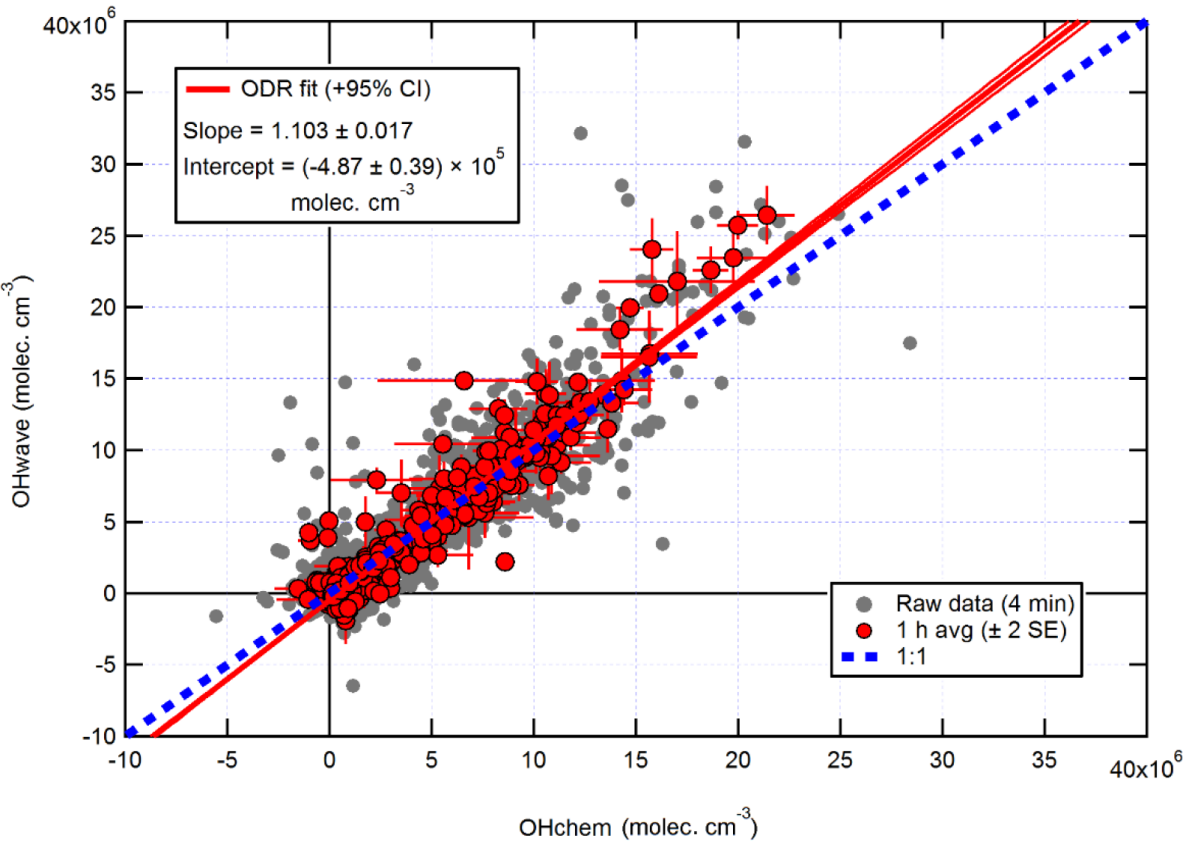

Figure 14. Overall intercomparison of $\mathrm{OH}_{\mathrm{wave}}$ and $\mathrm{OH}_{\mathrm{chem}}$ observations from the summer 2017 AIRPRO campaign. Grey markers represent raw data $(4 \mathrm{~min})$, with $1 \mathrm{~h}$ averages $( \pm 2 \mathrm{SE})$ in red. The thick red line is the ODR fit to the hourly data, with its $95 \%$ CI bands given by the thin red lines; fit errors are given at the $2 \sigma$ level. For comparison, $1: 1$ agreement is denoted by the dashed blue line. $\mathrm{OH}_{\mathrm{wave}}$ data were corrected for the known interference from $\mathrm{O}_{3}+\mathrm{H}_{2} \mathrm{O}$.

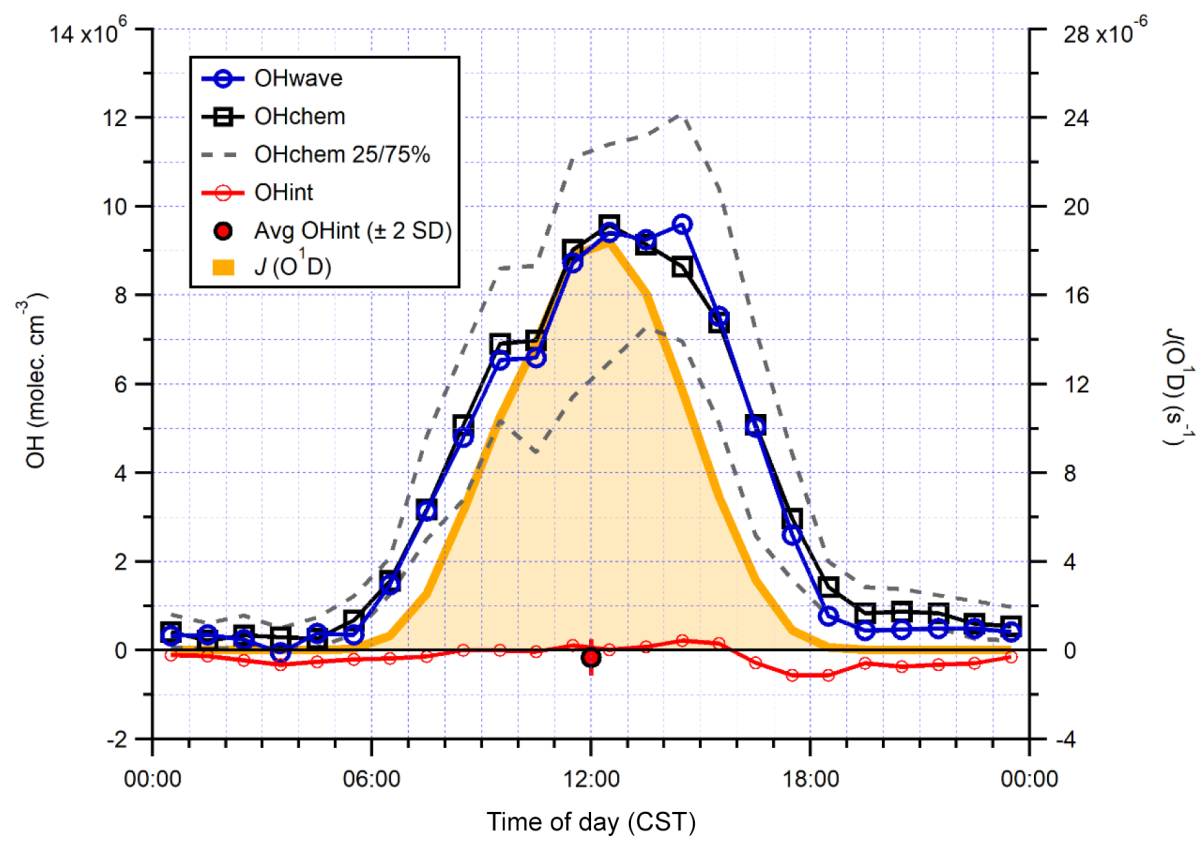

Figure 15. Hourly median diurnal profiles of $\mathrm{OH}_{\mathrm{wave}}, \mathrm{OH}_{\mathrm{chem}}$, and $J\left(\mathrm{O}^{1} \mathrm{D}\right)$ (right axis) from the summer 2017 AIRPRO campaign. Also shown (red line and markers) is the hourly median diurnal profile of $\mathrm{OH}_{\text {int }}$, calculated from individual 4 min data points; the single red marker corresponds to the average $( \pm 2 \sigma)$ of this trace. The variability (IQR) in $\mathrm{OH}_{\text {chem }}$ measurements is denoted by the dashed grey lines and is not shown for others for clarity. $\mathrm{OH}_{\text {wave }}$ data were corrected for the known interference from $\mathrm{O}_{3}+\mathrm{H}_{2} \mathrm{O}$. 
It can be seen from Fig. 14 that there is a small cluster of points that lie significantly away from both the $1: 1$ and ODR regression lines, which are characterised by high $\mathrm{OH}_{\text {wave }}$ concentrations of $>1.5 \times 10^{7}$ molec. $\mathrm{cm}^{-3}$. This finding was investigated further, with the results summarised in Fig. 16. Above an $\mathrm{OH}_{\text {chem }}$ threshold of $\sim 1.0-1.5 \times 10^{7}$ molec. $\mathrm{cm}^{-3}$, the $\mathrm{OH}_{\text {int }}$ signal becomes significantly greater than zero and the instrument LOD, reaching $\sim 3-5 \times 10^{6}$ molec. $\mathrm{cm}^{-3}$ at

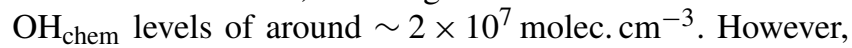
these results should be treated with caution, since only a few points are available for which $\mathrm{OH}_{\text {chem }}$ was present at such high concentrations. The same behaviour was not observed for either the AIRPRO winter or ICOZA campaigns, since

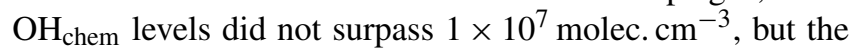
analogous mean values at low $\mathrm{OH}_{\text {chem }}$ concentrations are in agreement with the AIRPRO summer results.

The above results suggest that in the Beijing summertime, the Leeds FAGE instrument is subject to an interference(s) at the highest $\mathrm{OH}$ levels, although its contribution of $\sim 15 \%-$ $20 \%$ (Fig. 16) is still below the instrumental accuracy of $26 \%$ at $2 \sigma$. This finding is consistent with the suggestion of Fittschen et al. (2019) that ROOOH species, formed from $\mathrm{RO}_{2}+\mathrm{OH}$ reactions, generate an $\mathrm{OH}$ interference in LIFFAGE instruments, since high $\mathrm{OH}$ levels would generate high $\mathrm{RO}_{2}$ concentrations and favour this class of reaction. It is also possible that, for high ambient $\mathrm{OH}$ production rates, the scavenger cannot react with the sampled $\mathrm{OH}$ sufficiently quickly, leading to elevated but spurious $\mathrm{OH}_{\text {chem }}$ background signals. Although a modelling study of the inlet chemistry would be required to fully assess this hypothesis, it is likely not the case considering that the propane concentration used during AIRPRO results in an $\mathrm{OH}$ lifetime of $\sim 0.03 \mathrm{~ms}$ in the IPI flow tube, in comparison to a residence time of $\sim 20 \mathrm{~ms}$ (i.e. $\sim 700$ OH lifetimes).

No clear dependences were found when $\mathrm{OH}_{\text {int }}$ was binned against various parameters previously implicated in $\mathrm{OH}$ measurement interferences (Fig. S2), although it can be seen that $\mathrm{OH}_{\text {int }}$ was marginally higher in the highest temperature, $J\left(\mathrm{O}^{1} \mathrm{D}\right)$, and isoprene bins.

\section{Discussion}

The results from the three field campaigns that feature in this work demonstrate that, in moderately to highly polluted conditions, the Leeds ground-based FAGE instrument does not suffer from substantial interferences in the measurement of $\mathrm{OH}$ using the conventional, wavelength modulation background technique, $\mathrm{OH}_{\text {wave }}$. This is illustrated best by the slopes of the overall measurement intercomparison plots (Figs. 10, 12, and 14), which ranged from 1.05 to 1.16. However, while the deviations of these slopes from 1 are small, they are still significant, suggesting the presence of unknown $\mathrm{OH}$ interferences. Nonetheless, such unknown interferences are well within the instrumental uncertainty of $\sim 26 \%$ at $2 \sigma$.
With respect to previous studies during which $\mathrm{OH}$ has been measured by a LIF instrument equipped with a scavenger injector, the significance of interferences during the campaigns that feature in this work are amongst the lowest observed (Table 4). This can likely be attributed to two main factors: environment and instrumental. In terms of the former, none of the field campaigns described in the present study took place in forested environments, where the most significant interferences have been observed (Mao et al., 2012; Novelli et al., 2014a; Feiner et al., 2016). However, as mentioned previously, the AIRPRO summer campaign did share some characteristics, in that high BVOC and low NO mixing ratios were observed in the afternoon. Despite this, $\mathrm{OH}_{\text {wave }}$ and $\mathrm{OH}_{\text {chem }}$ were in good agreement. Although AIRPRO summer took place in a city, its results do provide confidence in previous measurements of $\mathrm{OH}$ using the same instrument, and support the hypothesis that there are unknown $\mathrm{OH}$ sources in the atmosphere.

The insignificance of daytime interferences during the AIRPRO campaigns is consistent with results of another urban study, CalNex-LA (Research in California at the Nexus of Air Quality and Climate Change) (Griffith et al., 2016). The $\mathrm{O}_{3} / \mathrm{H}_{2} \mathrm{O}$ interference is much higher (up to $\sim 4 \times 10^{6}$ molec. $\mathrm{cm}^{-3} \mathrm{OH}$ equivalent during CalNexLA) in the Indiana University (IU) LIF instrument (Dusanter et al., 2009), such that the daytime contributions of $\sim 33 \%$ can be explained entirely by this known interference. However, measurements made at a nearby site during the same study (CalNex-SJV) showed daytime contributions of $\sim 20 \%$ (Brune et al., 2016), although this may be related to instrumental differences, as discussed below. On average, interferences were not observed in the daytime during ICOZA, but they were observed in other coastal campaigns, namely DOMINO (Diel Oxidants Mechanisms In relation to Nitrogen Oxide), $\mathrm{HO}_{x}(\sim 50 \%)$ (Novelli et al., 2014a), and CYPHEX (CYprus PHotochemistry EXperiment, $\sim 45 \%$ ) (Mallik et al., 2018), as well as in rural regions, such as HOPE (Hohenpeißenberg Photochemistry Experiment, $20 \%-40 \%$ ) (Novelli et al., 2014a). Studies of the North China Plain have revealed small interferences on the order of $0 \%-10 \%$ (Tan et al., 2017, 2018), with slightly higher but variable contributions of $0 \%-20 \%$ in the Pearl River Delta (Tan et al., 2019).

The second major reason for the differences in contributions between the studies listed in Table 4 is likely instrumental effects. For the campaigns in which the highest $\mathrm{OH}$ interferences have been observed (Mao et al., 2012; Novelli et al., 2014b; Feiner et al., 2016), OH measurements were made using the Max Planck Institute (MPI) (Martinez et al., 2010) and PSU (Faloona et al., 2004) LIF instruments. These instruments feature laser multi-pass detection cells, which give rise to larger detection volumes and increased UV fluence, although this may not be relevant considering that the interference signals did not display any laser power dependence for these instruments. The Leeds instrument also differs in 


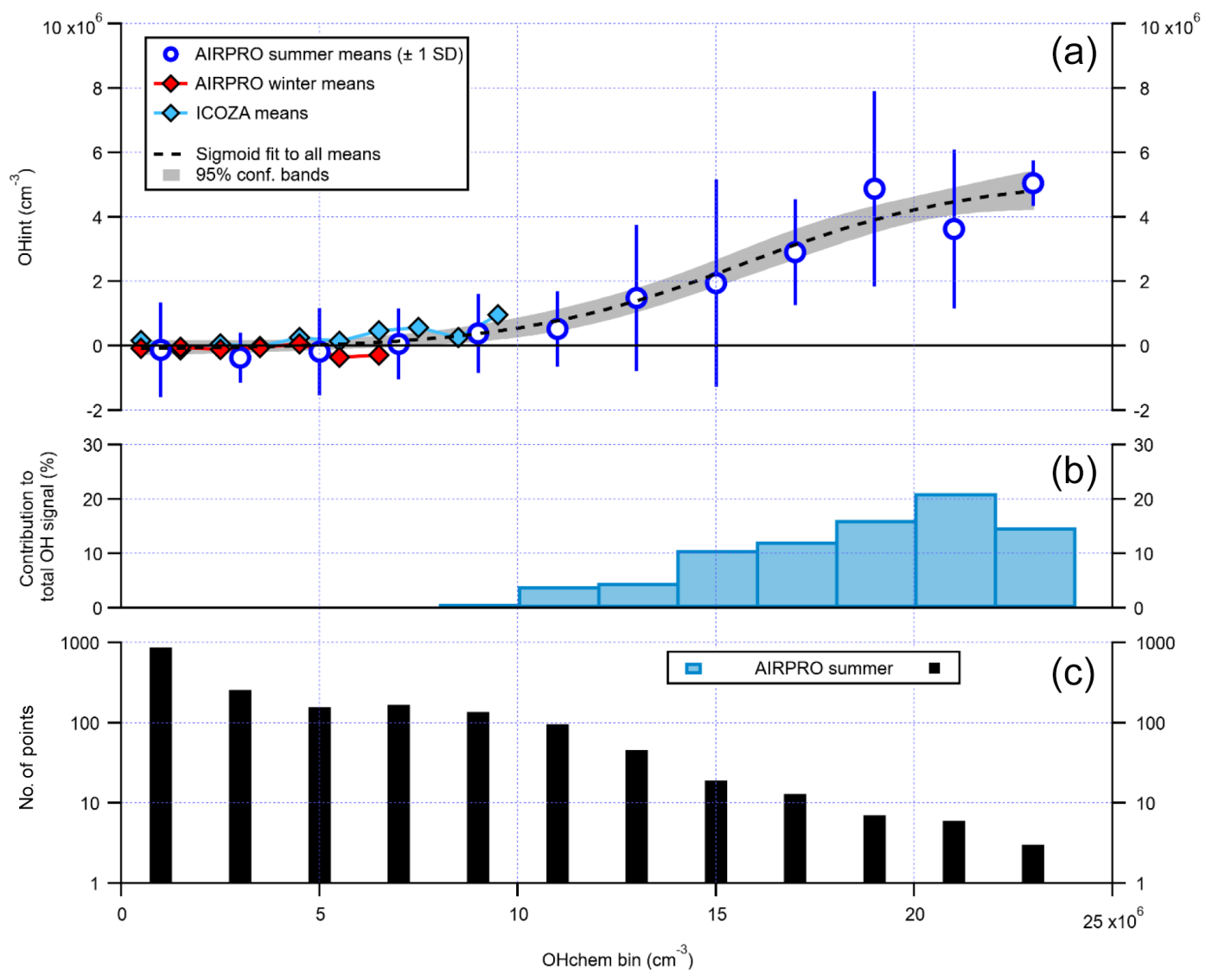

Figure 16. The relationship between $\mathrm{OH}_{\text {int }}$ and $\mathrm{OH}_{\text {chem }}$ using binned data. The error bars for AIRPRO summer (a, blue markers) denote $1 \mathrm{SD}$ and are not shown for AIRPRO winter and ICOZA for clarity. The dashed black line corresponds to a sigmoid fit and is used to guide the eye only. The contribution of interferences to the total $\mathrm{OH}_{\text {wave }}$ signal $\left(=\mathrm{OH}_{\text {int }} / \mathrm{OH}_{\mathrm{wave}} \times 100 \%\right)$ for the AIRPRO summer campaign is shown in (b), with the number of points in each bin shown in (c). All $\mathrm{OH}_{\text {int }}$ data used here have been corrected for the known interference from $\mathrm{O}_{3}+\mathrm{H}_{2} \mathrm{O}$.

terms of cell geometry, where the $\mathrm{HO}_{x}$ cell is composed of a short $(5 \mathrm{~cm})$ turreted inlet on top of a large fluorescence cell (additional $\sim 8 \mathrm{~cm}$ to laser axis, $\sim 13 \mathrm{~cm}$ total length, and a cell diameter of $25 \mathrm{~cm}$ ). In contrast, the MPI and PSU instruments feature flow-tube-like inlets $(14-17 \mathrm{~cm}$ from the pinhole to laser axis) mounted on smaller fluorescence cells, facilitating the interaction of sampled gas with the cell walls, which may promote the generation of internal $\mathrm{OH}$. For the measurements listed in Table 4, the Peking University (PKU) instrument (Tan et al., 2017) is most similar to the Leeds FAGE (i.e. single-pass detection, $\sim 10 \mathrm{~cm}$ total length from sampling inlet to laser axis), for which similar daytime interferences on the order of $\sim 0 \%-20 \%$ were observed.

For the ICOZA campaign, nothing could be inferred about the origin of the $\mathrm{OH}$ interference signal when one was observed, as it did not exhibit any characteristic diurnal profile (Fig. 11), and showed no obvious dependences on a variety of meteorological and chemical parameters. This finding is in contrast to previous studies in which diel profiles (Mao et al., 2012; Feiner et al., 2016) and dependences (Mao et al., 2012; Feiner et al., 2016; Novelli et al., 2017) of the interference have been observed. The occurrence of large (i.e. $>1 \times 10^{6}$ molec. $\left.\mathrm{cm}^{-3}\right)$ background $\mathrm{OH}$ signals $\left(\mathrm{OH}_{\mathrm{int}}=\right.$ $\mathrm{OH}_{\mathrm{wave}}-\mathrm{OH}_{\text {chem }}$ ) after instrumental problems (e.g. power cuts, data not shown) implies that the differences may have been instrumental rather than as a result of a species present in ambient air, although the data at these times did pass all quality control filters and therefore could not be rejected. Nonetheless, any differences are still a concern, regardless of their cause; the IPI system thus serves as an additional check on measurement accuracy and operational stability, and is perhaps most useful for fieldwork sites where power supplies are unreliable, for example in more remote areas.

It is possible that, even though the background $\mathrm{OH}$ had a flat diurnal profile in each field campaign, the species responsible for any interference observed were different between daytime and night-time periods. Thus, analysis of the daytime and night-time data separately, as a function of the same parameters, might reveal more information. Considering the recent identification of $\mathrm{NO}_{3}$ radicals as an internal 
Table 4. Average contributions of FAGE background signals to the total $\mathrm{OH}$ measured $\left(=\left(\mathrm{OH}_{\mathrm{wave}}-\mathrm{OH}_{\mathrm{chem}}\right) / \mathrm{OH}_{\mathrm{wave}}\right)$ during ambient air studies where a chemical modulation technique was employed.

\begin{tabular}{|c|c|c|c|c|c|c|}
\hline \multirow[t]{2}{*}{ Study } & \multirow[t]{2}{*}{ Year } & \multirow[t]{2}{*}{ Location } & \multirow[t]{2}{*}{ Environment type } & \multicolumn{2}{|c|}{ Contribution (\%) } & \multirow[t]{2}{*}{ Reference(s) } \\
\hline & & & & Daytime & Night-time & \\
\hline PROPHET & 1998 & N Michigan & Forest, isoprene-dominated & Not tested & $\sim 0$ & Faloona et al. (2001) \\
\hline BEARPEX & 2009 & NE California & Forest, $\mathrm{MBO}$-dominated ${ }^{\mathrm{a}}$ & $40-60$ & 50 & Mao et al. (2012) \\
\hline CABINEX & 2009 & N Michigan & Forest, isoprene-dominated & Not tested & $50-100$ & Griffith et al. (2013) \\
\hline SHARP & 2009 & Houston, Texas & Urban & 30 & 50 & Ren et al. (2013) \\
\hline CalNex-LA & 2010 & Pasadena, California & Urban, downwind of LA & $33^{\mathrm{b}}$ & Not reported & Griffith et al. (2016) \\
\hline CalNex-SJV & 2010 & Bakersfield, California & Urban & 20 & 80 & Brune et al. (2016) \\
\hline DOMINO $\mathrm{HO}_{x}$ & 2010 & $\begin{array}{l}\text { El Arenosillo, near } \\
\text { Huelva, SW Spain }\end{array}$ & $\begin{array}{l}\text { Coastal, close to petrochemical } \\
\text { industry }\end{array}$ & 50 & 100 & Novelli et al. (2014) \\
\hline HUMPPA-COPEC & 2010 & Hyytiälä, SW Finland & Boreal forest, terpene-dominated & $60-80$ & 100 & $\begin{array}{l}\text { Hens et al. (2014); } \\
\text { Novelli et al. }(2014,2017)\end{array}$ \\
\hline HOPE & 2012 & Hohenpeissenberg, S Germany & Rural & $20-40$ & 100 & Novelli et al. $(2014,2017)$ \\
\hline SOAS & 2013 & Near Brent, Alabama & Forest, isoprene-dominated & 80 & $>70$ & Feiner et al. (2016) \\
\hline Wangdu & 2014 & North China Plain & Rural, urban influenced & 10 & Not reported & $\begin{array}{l}\text { Fuchs et al. (2017); } \\
\text { Tan et al. (2017) }\end{array}$ \\
\hline CYPHEX & 2014 & NW Cyprus & $\begin{array}{l}\text { Coastal, influenced by processed } \\
\text { European emissions }\end{array}$ & 45 & 100 & Mallik et al. (2018) \\
\hline PRIDE-PRD2014 & 2014 & Pearl River Delta & Suburban, $60 \mathrm{~km} \mathrm{SW}$ of Guangzhou & $<8$ & $0-20$ & Tan et al. (2019) \\
\hline BEST-ONE & 2016 & North China Plain & Suburban, $60 \mathrm{~km}$ NE of Beijing & $\sim 0$ & $\sim 0$ & Tan et al. (2018) \\
\hline ICOZA & 2015 & N Norfolk Coast, UK & Coastal, London outflow & $\sim 0$ & $\sim 0$ & This work \\
\hline AIRPRO Winter & 2016 & Beijing, China & Urban & $\sim 0$ & $\begin{array}{l}\text { Night-time } \mathrm{OH} \text { almost } \\
\text { always < LOD }\end{array}$ & This work \\
\hline AIRPRO Summer & 2017 & Beijing, China & Urban & $\sim 0$ & $\sim 0$ & This work \\
\hline
\end{tabular}

OH source in LIF instruments (Fuchs et al., 2016), and that $\mathrm{OH}$ concentrations have often been under-predicted at night (Faloona et al., 2001; Mao et al., 2012; Ren et al., 2013; Hens et al., 2014; Lu et al., 2014; Tan et al., 2017), this is perhaps the most interesting period for further study. However, for the data presented in this work, robust quantitative night-time analyses are not possible due to $\mathrm{OH}$ measurements being below or close to the instrument LOD.

In this work, there are several key findings that stand out. First, $\mathrm{OH}_{\text {wave }}$ and $\mathrm{OH}_{\text {chem }}$ were in good agreement even at the very low NO concentrations of $<100$ pptv during ICOZA and the moderate afternoon levels $(\sim 500 \mathrm{pptv}$ on average but often < 100 pptv; Shi et al., 2019) during the AIRPRO summer campaign. While the role of isoprene could not be assessed for ICOZA, due to the limited range of concentrations observed ( $<0.2 \mathrm{ppbv})$, it reached high levels during AIRPRO summer (up to $7.9 \mathrm{ppbv}$, larger than seen in some forested regions) but did not seem to perturb the agreement between the two measurements. In addition, very high levels of aromatic VOCs were observed during both AIRPRO winter and summer, where the agreement between $\mathrm{OH}_{\text {wave }}$ and $\mathrm{OH}_{\text {chem }}$ suggests that the intermediates of aromatic oxidation, such as exotic bicyclic species (Birdsall et al., 2010) and highly oxygenated molecules (HOMs) (Wang et al., 2017; Molteni et al., 2018; Tsiligiannis et al., 2019), do not give rise to $\mathrm{OH}$ interferences, which is postulated to be the case for intermediates (SCIs) in the ozone-oxidation of alkenes (Novelli et al., 2014b, 2017; Rickly and Stevens, 2018). However, the large alkene and ozone concentrations observed during AIRPRO summer should favour the formation of these SCIs, but sig- nificant interferences were not observed, consistent with laboratory investigations of the isoprene interference and casting doubt on the SCI hypothesis. Although, the AIRPRO SCI concentrations also depend on the magnitude of the SCI loss rates, which could be high if elevated levels of $\mathrm{SO}_{2}$ (Welz et al., 2012; Sheps et al., 2014) or organic acids (Welz et al., 2014) were present.

Considering the success of the first three field deployments of the IPI system and given that it does not reduce the instrument sensitivity towards $\mathrm{OH}$, it is suggested that the system is adopted for permanent use in ambient studies, although conventional sampling should still be performed from time-totime to check for potential artefacts caused by the IPI system itself. Another advantage of the IPI system is that it reduces the amount of solar light entering the pinhole, which reduces the size and variability of daytime background signals and therefore improves signal-to-noise and hence detection limits. It is recommended that the IPI propane concentration is kept the same as the summer AIRPRO campaign, as it is possible that the slightly poorer agreement between $\mathrm{OH}_{\text {wave }}$ and $\mathrm{OH}_{\text {chem }}$ during ICOZA was because of the lower propane flow used (i.e. the flow was not sufficient to ensure that $\mathrm{OH}$ generated from all steady-state sources was removed), although this cannot be verified.

Future field campaigns using the IPI will allow for the assessment of interferences in the Leeds FAGE instrument for a range of different environments. From these, the contribution of interferences for previous studies in similar environments, where measurements were made prior to the discovery of significant interferences in the LIF measurement of $\mathrm{OH}$ reported 
by others, may be inferred. The measurement-model comparisons may then be reassessed in light of any new information regarding the accuracy of $\mathrm{OH}$ measurements. Regardless of the reasons for any differences between the two measures of $\mathrm{OH}$ (i.e. chemical interferences or instrumental problems such as during recovery periods after power cuts), the IPI system serves as an additional check on $\mathrm{OH}$ observations, increasing confidence in the validity of the data obtained.

\section{Conclusions}

The addition of an IPI system to the Leeds ground-based FAGE instrument allowed for a comprehensive investigation of $\mathrm{OH}$ measurement interferences in both the laboratory and the field. Following its optimisation and thorough characterisation in terms of sensitivity and external and internal $\mathrm{OH}$ removal efficiency, laboratory experiments were conducted to assess potential interferences from (1) the photolysis of $\mathrm{O}_{3}$ in the presence of $\mathrm{H}_{2} \mathrm{O}$ vapour, (2) the intermediates and products of isoprene ozonolysis, and (3) $\mathrm{NO}_{3}$ radicals. For $\mathrm{O}_{3}+\mathrm{H}_{2} \mathrm{O}$, a small but potentially significant interference (at high $\mathrm{O}_{3}$ levels) was found, but interferences from isoprene ozonolysis products and $\mathrm{NO}_{3}$ radicals were shown to be insignificant under typical atmospheric conditions.

Field campaigns conducted in the UK and China showed that, on average, the Leeds ground-based FAGE instrument does not suffer from significant interferences in the detection of $\mathrm{OH}$. It was only under the very high $\mathrm{OH}$ levels of $>1.5 \times$ $10^{7}$ molec. $\mathrm{cm}^{-3}$ sometimes observed during the AIRPRO summer campaign that interferences were found consistently, although their contributions $(\sim 15 \%-20 \%)$ were smaller than the instrumental accuracy of $26 \%$ at $2 \sigma$. Large interference signals $\left(>1 \times 10^{6}\right.$ molec. $\left.\mathrm{cm}^{-3}\right)$ were occasionally observed during the ICOZA campaign but always after instrumental problems such as power cuts, suggesting that the $\mathrm{OH}_{\text {chem }}$ method serves as an additional tool for verifying instrument stability and validating measurements. The Leeds IPI system will find continued use in future fieldwork.

Data availability. Data presented in this study are available from the authors upon request (1.k.whalley@leeds.ac.uk and d.e.heard@leeds.ac.uk).

Supplement. The supplement related to this article is available online at: https://doi.org/10.5194/amt-13-3119-2020-supplement.

Author contributions. RWM, TI, LKW, and DEH designed the IPI system. RWM, EJS, JA, LMS, CY, and LKW performed laboratory experiments. RWM, EJS, DRC, CY, LKW, and DEH were responsible for field measurements. RWM, EJS, and LKW analysed the data. RWM wrote the manuscript with input from all co-authors.
Competing interests. The authors declare that they have no conflict of interest.

Acknowledgements. Robert Woodward-Massey, Danny R. Cryer, and Eloise J. Slater are grateful to NERC for funding $\mathrm{PhD}$ studentships. We would like to acknowledge Brian Bandy, Grant Forster, David Oram, and Claire Reeves (University of East Anglia); William Bloss, Leigh Crilley, and Louisa Kramer (University of Birmingham); and Rachel Dunmore, Jacqui Hamilton, James Hopkins, James Lee, Chris Reed, and Freya Squires (University of York) for the provision of some of the data used to generate the averages in Table 1. We would also like to thank other participants in the ICOZA and AIRPRO field campaigns. We are grateful for technical support from the University of Leeds mechanical and electronics workshops. Robert Woodward-Massey is grateful to Hans Osthoff (University of Calgary) for the provision of Igor functions.

Financial support. This research has been supported by the NERC (grant nos. NE/K012029/1, NE/K012169/1, NE/N007115/1, and NE/N006895/1).

Review statement. This paper was edited by Anna Novelli and reviewed by two anonymous referees.

\section{References}

Birdsall, A. W., Andreoni, J. F., and Elrod, M. J.: Investigation of the role of bicyclic peroxy radicals in the oxidation mechanism of toluene, J. Phys. Chem. A, 114, 10655-10663, https://doi.org/10.1021/jp105467e, 2010.

Bloss, W. J., Lee, J. D., Heard, D. E., Salmon, R. A., Bauguitte, S. J.-B., Roscoe, H. K., and Jones, A. E.: Observations of $\mathrm{OH}$ and $\mathrm{HO}_{2}$ radicals in coastal Antarctica, Atmos. Chem. Phys., 7, 4171-4185, https://doi.org/10.5194/acp-7-4171-2007, 2007.

Boggs, P. T., Byrd, R. H., and Schnabel, R. B.: A Stable and Efficient Algorithm for Nonlinear Orthogonal Distance Regression, Siam J. Sci. Stat. Comp., 8, 1052-1078, https://doi.org/10.1137/0908085, 1987.

Bohn, B., Corlett, G. K., Gillmann, M., Sanghavi, S., Stange, G., Tensing, E., Vrekoussis, M., Bloss, W. J., Clapp, L. J., Kortner, M., Dorn, H.-P., Monks, P. S., Platt, U., Plass-Dülmer, C., Mihalopoulos, N., Heard, D. E., Clemitshaw, K. C., Meixner, F. X., Prevot, A. S. H., and Schmitt, R.: Photolysis frequency measurement techniques: results of a comparison within the ACCENT project, Atmos. Chem. Phys., 8, 5373-5391, https://doi.org/10.5194/acp-8-5373-2008, 2008.

Brune, W. H., Baier, B. C., Thomas, J., Ren, X., Cohen, R. C., Pusede, S. E., Browne, E. C., Goldstein, A. H., Gentner, D. R., Keutsch, F. N., Thornton, J. A., Harrold, S., Lopez-Hilfiker, F. D., and Wennberg, P. O.: Ozone production chemistry in the presence of urban plumes, Faraday Discuss., 189, 169-189, https://doi.org/10.1039/c5fd00204d, 2016.

Carslaw, N., Creasey, D. J., Harrison, D., Heard, D. E., Hunter, M. C., Jacobs, P. J., Jenkin, M. E., Lee, J. D., Lewis, A. C., 
Pilling, M. J., Saunders, S. M., and Seakins, P. W.: $\mathrm{OH}$ and $\mathrm{HO}_{2}$ radical chemistry in a forested region of north-western Greece, Atmos. Environ., 35, 4725-4737, https://doi.org/10.1016/S13522310(01)00089-9, 2001.

Cazorla, M. and Brune, W. H.: Measurement of Ozone Production Sensor, Atmos. Meas. Tech., 3, 545-555, https://doi.org/10.5194/amt-3-545-2010, 2010.

Cazorla, M., Brune, W. H., Ren, X., and Lefer, B.: Direct measurement of ozone production rates in Houston in 2009 and comparison with two estimation methods, Atmos. Chem. Phys., 12, 1203-1212, https://doi.org/10.5194/acp-12-1203-2012, 2012.

Chao, W., Hsieh, J. T., Chang, C. H., and Lin, J. J.: Atmospheric chemistry. Direct kinetic measurement of the reaction of the simplest Criegee intermediate with water vapor, Science, 347, 751754, https://doi.org/10.1126/science.1261549, 2015.

Chen, W., Tang, H. Z., and Zhao, H. M.: Diurnal, weekly and monthly spatial variations of air pollutants and air quality of Beijing, Atmos. Environ., 119, 21-34, https://doi.org/10.1016/j.atmosenv.2015.08.040, 2015.

Creasey, D. J., HalfordMaw, P. A., Heard, D. E., Pilling, M. J., and Whitaker, B. J.: Implementation and initial deployment of a field instrument for measurement of $\mathrm{OH}$ and $\mathrm{HO}_{2}$ in the troposphere by laser-induced fluorescence, J. Chem. Soc.-Faraday T., 93, 2907-2913, https://doi.org/10.1039/a701469d, 1997a.

Creasey, D. J., Heard, D. E., Pilling, M. J., Whitaker, B. J., Berzins, M., and Fairlie, R.: Visualisation of a supersonic free-jet expansion using laser-induced fluorescence spectroscopy: Application to the measurement of rate constants at ultralow temperatures, Appl. Phys. B, 65, 375-391, https://doi.org/10.1007/s003400050285, 1997b.

Creasey, D. J., Heard, D. E., and Lee, J. D.: OH and $\mathrm{HO}_{2}$ measurements in a forested region of north-western Greece, Atmos. Environ., 35, 4713-4724, https://doi.org/10.1016/S13522310(01)00090-5, 2001.

Creasey, D. J., Evans, G. E., Heard, D. E., and Lee, J. D.: Measurements of $\mathrm{OH}$ and $\mathrm{HO}_{2}$ concentrations in the Southern Ocean marine boundary layer, J. Geophys. Res.-Atmos., 108, 4475, 10.1029/2002JD003206, 2003.

Crounse, J. D., Paulot, F., Kjaergaard, H. G., and Wennberg, P. O.: Peroxy radical isomerization in the oxidation of isoprene, Phys. Chem. Chem. Phys., 13, 13607-13613, https://doi.org/10.1039/c1cp21330j, 2011.

Crounse, J. D., Knap, H. C., Ornso, K. B., Jorgensen, S., Paulot, F., Kjaergaard, H. G., and Wennberg, P. O.: Atmospheric fate of methacrolein. 1. Peroxy radical isomerization following addition of $\mathrm{OH}$ and $\mathrm{O}_{2}$, J. Phys. Chem. A, 116, 5756-5762, https://doi.org/10.1021/jp211560u, 2012.

Cryer, D. R.: Measurements of hydroxyl radical reactivity and formaldehyde in the atmosphere, $\mathrm{PhD}$ thesis, School of Chemistry, University of Leeds, 2016.

da Silva, G., Graham, C., and Wang, Z. F.: Unimolecular betahydroxyperoxy radical decomposition with $\mathrm{OH}$ recycling in the photochemical oxidation of isoprene, Environ. Sci. Technol., 44, 250-256, https://doi.org/10.1021/es900924d, 2010.

Dillon, T. J. and Crowley, J. N.: Direct detection of $\mathrm{OH}$ formation in the reactions of $\mathrm{HO}_{2}$ with $\mathrm{CH}_{3} \mathrm{C}(\mathrm{O}) \mathrm{O}_{2}$ and other substituted peroxy radicals, Atmos. Chem. Phys., 8, 4877-4889, https://doi.org/10.5194/acp-8-4877-2008, 2008.
Dubey, M. K., Hanisco, T. F., Wennberg, P. O., and Anderson, J. G.: Monitoring potential photochemical interference in laser-induced fluorescence measurements of atmospheric OH, Geophys. Res. Lett., 23, 3215-3218, https://doi.org/10.1029/96gl03008, 1996.

Dusanter, S., Vimal, D., Stevens, P. S., Volkamer, R., and Molina, L. T.: Measurements of $\mathrm{OH}$ and $\mathrm{HO}_{2}$ concentrations during the MCMA-2006 field campaign - Part 1: Deployment of the Indiana University laser-induced fluorescence instrument, Atmos. Chem. Phys., 9, 1665-1685, https://doi.org/10.5194/acp-9-16652009, 2009.

Edwards, G. D., Cantrell, C. A., Stephens, S., Hill, B., Goyea, O., Shetter, R. E., Mauldin, R. L., Kosciuch, E., Tanner, D. J., and Eisele, F. L.: Chemical ionization mass spectrometer instrument for the measurement of tropospheric $\mathrm{HO}_{2}$ and $\mathrm{RO}_{2}$, Anal. Chem., 75, 5317-5327, https://doi.org/10.1021/ac034402b, 2003.

Emmerson, K. M., Carslaw, N., Carslaw, D. C., Lee, J. D., McFiggans, G., Bloss, W. J., Gravestock, T., Heard, D. E., Hopkins, J., Ingham, T., Pilling, M. J., Smith, S. C., Jacob, M., and Monks, P. S.: Free radical modelling studies during the UK TORCH Campaign in Summer 2003, Atmos. Chem. Phys., 7, 167-181, https://doi.org/10.5194/acp-7-167-2007, 2007.

Faloona, I., Tan, D., Brune, W., Hurst, J., Barket, D., Couch, T. L., Shepson, P., Apel, E., Riemer, D., Thornberry, T., Carroll, M. A., Sillman, S., Keeler, G. J., Sagady, J., Hooper, D., and Paterson, K.: Nighttime observations of anomalously high levels of hydroxyl radicals above a deciduous forest canopy, J. Geophys. Res.-Atmos., 106, 24315-24333, https://doi.org/10.1029/2000jd900691, 2001.

Faloona, I. C., Tan, D., Lesher, R. L., Hazen, N. L., Frame, C. L., Simpas, J. B., Harder, H., Martinez, M., Di Carlo, P., Ren, X. R., and Brune, W. H.: A laser-induced fluorescence instrument for detecting tropospheric $\mathrm{OH}$ and $\mathrm{HO}_{2}$ : Characteristics and calibration, J. Atmos. Chem., 47, 139-167, https://doi.org/10.1023/B:JOCH.0000021036.53185.0e, 2004.

Feiner, P. A., Brune, W. H., Miller, D. O., Zhang, L., Cohen, R. C., Romer, P. S., Goldstein, A. H., Keutsch, F. N., Skog, K. M., Wennberg, P. O., Nguyen, T. B., Teng, A. P., DeGouw, J., Koss, A., Wild, R. J., Brown, S. S., Guenther, A., Edgerton, E., Baumann, K., and Fry, J. L.: Testing Atmospheric Oxidation in an Alabama Forest, J. Atmos. Sci., 73, 4699-4710, https://doi.org/10.1175/Jas-D-16-0044.1, 2016.

Fittschen, C., Al Ajami, M., Batut, S., Ferracci, V., ArcherNicholls, S., Archibald, A. T., and Schoemaecker, C.: ROOOH: a missing piece of the puzzle for $\mathrm{OH}$ measurements in low-NO environments?, Atmos. Chem. Phys., 19, 349-362, https://doi.org/10.5194/acp-19-349-2019, 2019.

Fuchs, H., Holland, F., and Hofzumahaus, A.: Measurement of tropospheric $\mathrm{RO}_{2}$ and $\mathrm{HO}_{2}$ radicals by a laser-induced fluorescence instrument, Rev. Sci. Instrum., 79, 084104, https://doi.org/10.1063/1.2968712, 2008.

Fuchs, H., Bohn, B., Hofzumahaus, A., Holland, F., Lu, K. D., Nehr, S., Rohrer, F., and Wahner, A.: Detection of $\mathrm{HO}_{2}$ by laser-induced fluorescence: calibration and interferences from $\mathrm{RO}_{2}$ radicals, Atmos. Meas. Tech., 4, 1209-1225, https://doi.org/10.5194/amt-4-1209-2011, 2011.

Fuchs, H., Hofzumahaus, A., Rohrer, F., Bohn, B., Brauers, T., Dorn, H. P., Haseler, R., Holland, F., Kaminski, M., Li, X., 
Lu, K., Nehr, S., Tillmann, R., Wegener, R., and Wahner, A.: Experimental evidence for efficient hydroxyl radical regeneration in isoprene oxidation, Nat. Geosci., 6, 1023-1026, https://doi.org/10.1038/Ngeo1964, 2013.

Fuchs, H., Acir, I.-H., Bohn, B., Brauers, T., Dorn, H.-P., Häseler, R., Hofzumahaus, A., Holland, F., Kaminski, M., Li, X., Lu, K., Lutz, A., Nehr, S., Rohrer, F., Tillmann, R., Wegener, R., and Wahner, A.: $\mathrm{OH}$ regeneration from methacrolein oxidation investigated in the atmosphere simulation chamber SAPHIR, Atmos. Chem. Phys., 14, 7895-7908, https://doi.org/10.5194/acp14-7895-2014, 2014.

Fuchs, H., Tan, Z., Hofzumahaus, A., Broch, S., Dorn, H.-P., Holland, F., Künstler, C., Gomm, S., Rohrer, F., Schrade, S., Tillmann, R., and Wahner, A.: Investigation of potential interferences in the detection of atmospheric $\mathrm{RO}_{x}$ radicals by laserinduced fluorescence under dark conditions, Atmos. Meas. Tech., 9, 1431-1447, https://doi.org/10.5194/amt-9-1431-2016, 2016.

Fuchs, H., Tan, Z., Lu, K., Bohn, B., Broch, S., Brown, S. S., Dong, H., Gomm, S., Häseler, R., He, L., Hofzumahaus, A., Holland, F., Li, X., Liu, Y., Lu, S., Min, K.-E., Rohrer, F., Shao, M., Wang, B., Wang, M., Wu, Y., Zeng, L., Zhang, Y., Wahner, A., and Zhang, Y.: OH reactivity at a rural site (Wangdu) in the North China Plain: contributions from $\mathrm{OH}$ reactants and experimental $\mathrm{OH}$ budget, Atmos. Chem. Phys., 17, 645-661, https://doi.org/10.5194/acp-17-645-2017, 2017.

Fuchs, H., Albrecht, S., Acir, I., Bohn, B., Breitenlechner, M., Dorn, H.-P., Gkatzelis, G. I., Hofzumahaus, A., Holland, F., Kaminski, M., Keutsch, F. N., Novelli, A., Reimer, D., Rohrer, F., Tillmann, R., Vereecken, L., Wegener, R., Zaytsev, A., Kiendler-Scharr, A., and Wahner, A.: Investigation of the oxidation of methyl vinyl ketone (MVK) by $\mathrm{OH}$ radicals in the atmospheric simulation chamber SAPHIR, Atmos. Chem. Phys., 18, 8001-8016, https://doi.org/10.5194/acp-18-8001-2018, 2018.

Griffith, S. M., Hansen, R. F., Dusanter, S., Stevens, P. S., Alaghmand, M., Bertman, S. B., Carroll, M. A., Erickson, M., Galloway, M., Grossberg, N., Hottle, J., Hou, J., Jobson, B. T., Kammrath, A., Keutsch, F. N., Lefer, B. L., Mielke, L. H., O'Brien, A., Shepson, P. B., Thurlow, M., Wallace, W., Zhang, N., and Zhou, X. L.: $\mathrm{OH}$ and $\mathrm{HO}_{2}$ radical chemistry during PROPHET 2008 and CABINEX 2009 - Part 1: Measurements and model comparison, Atmos. Chem. Phys., 13, 5403-5423, https://doi.org/10.5194/acp-13-5403-2013, 2013.

Griffith, S. M., Hansen, R. F., Dusanter, S., Michoud, V., Gilman, J. B., Kuster, W. C., Veres, P. R., Graus, M., de Gouw, J. A., Roberts, J., Young, C., Washenfelder, R., Brown, S. S., Thalman, R., Waxman, E., Volkamer, R., Tsai, C., Stutz, J., Flynn, J. H., Grossberg, N., Lefer, B., Alvarez, S. L., Rappenglueck, B., Mielke, L. H., Osthoff, H. D., and Stevens, P. S.: Measurements of hydroxyl and hydroperoxy radicals during CalNex-LA: Model comparisons and radical budgets, J. Geophys. Res.-Atmos., 121, 4211-4232, https://doi.org/10.1002/2015jd024358, 2016.

Hansen, R. F., Lewis, T. R., Graham, L., Whalley, L. K., Seakins, P. W., Heard, D. E., and Blitz, M. A.: OH production from the photolysis of isoprene-derived peroxy radicals: cross-sections, quantum yields and atmospheric implications, Phys. Chem. Chem. Phys., 19, 2332-2345, https://doi.org/10.1039/c6cp06718b, 2017.

Hard, T. M., Obrien, R. J., Chan, C. Y., and Mehrabzadeh, A. A.: Tropospheric Free-Radical Determination by fluores- cence by gas expansion, Environ. Sci. Technol., 18, 768-777, https://doi.org/10.1021/es00128a009, 1984.

Heard, D. E., Carpenter, L. J., Creasey, D. J., Hopkins, J. R., Lee, J. D., Lewis, A. C., Pilling, M. J., Seakins, P. W., Carslaw, N., and Emmerson, K. M.: High levels of the hydroxyl radical in the winter urban troposphere, Geophys. Res. Lett., 31, L18112, https://doi.org/10.1029/2004GL020544, 2004.

Hens, K., Novelli, A., Martinez, M., Auld, J., Axinte, R., Bohn, B., Fischer, H., Keronen, P., Kubistin, D., Nölscher, A. C., Oswald, R., Paasonen, P., Petäjä, T., Regelin, E., Sander, R., Sinha, V., Sipilä, M., Taraborrelli, D., Tatum Ernest, C., Williams, J., Lelieveld, J., and Harder, H.: Observation and modelling of $\mathrm{HO}_{\mathrm{x}}$ radicals in a boreal forest, Atmos. Chem. Phys., 14, 8723-8747, https://doi.org/10.5194/acp-14-8723-2014, 2014.

Hewitt, C. N., Lee, J. D., MacKenzie, A. R., Barkley, M. P., Carslaw, N., Carver, G. D., Chappell, N. A., Coe, H., Collier, C., Commane, R., Davies, F., Davison, B., DiCarlo, P., Di Marco, C. F., Dorsey, J. R., Edwards, P. M., Evans, M. J., Fowler, D., Furneaux, K. L., Gallagher, M., Guenther, A., Heard, D. E., Helfter, C., Hopkins, J., Ingham, T., Irwin, M., Jones, C., Karunaharan, A., Langford, B., Lewis, A. C., Lim, S. F., MacDonald, S. M., Mahajan, A. S., Malpass, S., McFiggans, G., Mills, G., Misztal, P., Moller, S., Monks, P. S., Nemitz, E., Nicolas-Perea, V., Oetjen, H., Oram, D. E., Palmer, P. I., Phillips, G. J., Pike, R., Plane, J. M. C., Pugh, T., Pyle, J. A., Reeves, C. E., Robinson, N. H., Stewart, D., Stone, D., Whalley, L. K., and Yin, X.: Overview: oxidant and particle photochemical processes above a south-east Asian tropical rainforest (the OP3 project): introduction, rationale, location characteristics and tools, Atmos. Chem. Phys., 10, 169-199, https://doi.org/10.5194/acp-10-169-2010, 2010.

Hofzumahaus, A. and Heard, D. E.: Assessment of Local $\mathrm{HO}_{x}$ and $\mathrm{RO}_{x}$ Measurement Techniques: Achievements, Challenges, and Future Directions - Outcomes of the 2015 International $\mathrm{HO}_{x}$ Workshop, IGAG News, 55, 20-21, 2015.

Hofzumahaus, A., Rohrer, F., Lu, K., Bohn, B., Brauers, T., Chang, C. C., Fuchs, H., Holland, F., Kita, K., Kondo, Y., Li, X., Lou, S., Shao, M., Zeng, L., Wahner, A., and Zhang, Y.: Amplified trace gas removal in the troposphere, Science, 324, 1702-1704, https://doi.org/10.1126/science.1164566, 2009.

Lee, J. D., Whalley, L. K., Heard, D. E., Stone, D., Dunmore, R. E., Hamilton, J. F., Young, D. E., Allan, J. D., Laufs, S., and K1effmann, J.: Detailed budget analysis of HONO in central London reveals a missing daytime source, Atmos. Chem. Phys., 16, 2747-2764, https://doi.org/10.5194/acp-16-2747-2016, 2016.

Lelieveld, J., Butler, T. M., Crowley, J. N., Dillon, T. J., Fischer, H., Ganzeveld, L., Harder, H., Lawrence, M. G., Martinez, M., Taraborrelli, D., and Williams, J.: Atmospheric oxidation capacity sustained by a tropical forest, Nature, 452, 737-740, https://doi.org/10.1038/nature06870, 2008.

Lew, M. L., Rickly, P. S., Bottorff, B. P., Sklaveniti, S., Léonardis, T., Locoge, N., Dusanter, S., Kundu, S., Wood, E., and Stevens, P. S.: $\mathrm{OH}$ and $\mathrm{HO}_{2}$ radical chemistry in a midlatitude forest: Measurements and model comparisons, Atmos. Chem. Phys. Discuss., https://doi.org/10.5194/acp-2019-726, in review, 2019.

Lewis, T. R., Blitz, M. A., Heard, D. E., and Seakins, P. W.: Direct evidence for a substantive reaction between the Criegee intermediate, $\mathrm{CH}_{2} \mathrm{OO}$, and the water vapour dimer, Phys. Chem. Chem. Phys., 17, 4859-4863, https://doi.org/10.1039/c4cp04750h, 2015. 
Lin, L. C., Chao, W., Chang, C. H., Takahashi, K., and Lin, J. J.: Temperature dependence of the reaction of anti- $\mathrm{CH}_{3} \mathrm{CHOO}$ with water vapor, Phys. Chem. Chem. Phys., 18, 28189-28197, https://doi.org/10.1039/c6cp05171e, 2016.

Lu, K. D., Rohrer, F., Holland, F., Fuchs, H., Brauers, T., Oebel, A., Dlugi, R., Hu, M., Li, X., Lou, S. R., Shao, M., Zhu, T., Wahner, A., Zhang, Y. H., and Hofzumahaus, A.: Nighttime observation and chemistry of $\mathrm{HO}_{\mathrm{x}}$ in the Pearl River Delta and Beijing in summer 2006, Atmos. Chem. Phys., 14, 4979-4999, https://doi.org/10.5194/acp-14-4979-2014, 2014.

Mallik, C., Tomsche, L., Bourtsoukidis, E., Crowley, J. N., Derstroff, B., Fischer, H., Hafermann, S., Hüser, I., Javed, U., Keßel, S., Lelieveld, J., Martinez, M., Meusel, H., Novelli, A., Phillips, G. J., Pozzer, A., Reiffs, A., Sander, R., Taraborrelli, D., Sauvage, C., Schuladen, J., Su, H., Williams, J., and Harder, H.: Oxidation processes in the eastern Mediterranean atmosphere: evidence from the modelling of $\mathrm{HO}_{x}$ measurements over Cyprus, Atmos. Chem. Phys., 18, 10825-10847, https://doi.org/10.5194/acp-1810825-2018, 2018.

Mao, J., Ren, X., Zhang, L., Van Duin, D. M., Cohen, R. C., Park, J.-H., Goldstein, A. H., Paulot, F., Beaver, M. R., Crounse, J. D., Wennberg, P. O., DiGangi, J. P., Henry, S. B., Keutsch, F. N., Park, C., Schade, G. W., Wolfe, G. M., Thornton, J. A., and Brune, W. H.: Insights into hydroxyl measurements and atmospheric oxidation in a California forest, Atmos. Chem. Phys., 12, 8009-8020, https://doi.org/10.5194/acp-12-8009-2012, 2012.

Martinez, M., Harder, H., Ren, X., Lesher, R. L., and Brune, W. H.: Measuring atmospheric naphthalene with laserinduced fluorescence, Atmos. Chem. Phys., 4, 563-569, https://doi.org/10.5194/acp-4-563-2004, 2004.

Martinez, M., Harder, H., Kubistin, D., Rudolf, M., Bozem, H., Eerdekens, G., Fischer, H., Klüpfel, T., Gurk, C., Königstedt, R., Parchatka, U., Schiller, C. L., Stickler, A., Williams, J., and Lelieveld, J.: Hydroxyl radicals in the tropical troposphere over the Suriname rainforest: airborne measurements, Atmos. Chem. Phys., 10, 3759-3773, https://doi.org/10.5194/acp10-3759-2010, 2010.

Molteni, U., Bianchi, F., Klein, F., El Haddad, I., Frege, C., Rossi, M. J., Dommen, J., and Baltensperger, U.: Formation of highly oxygenated organic molecules from aromatic compounds, Atmos. Chem. Phys., 18, 1909-1921, https://doi.org/10.5194/acp18-1909-2018, 2018.

Newland, M. J., Rickard, A. R., Vereecken, L., Muñoz, A., Ródenas, M., and Bloss, W. J.: Atmospheric isoprene ozonolysis: impacts of stabilised Criegee intermediate reactions with $\mathrm{SO}_{2}$, $\mathrm{H}_{2} \mathrm{O}$ and dimethyl sulfide, Atmos. Chem. Phys., 15, 9521-9536, https://doi.org/10.5194/acp-15-9521-2015, 2015.

Nguyen, T. L., Vereecken, L., and Peeters, J.: HOx regeneration in the oxidation of isoprene III: theoretical study of the key isomerisation of the Z-delta-hydroxyperoxy isoprene radicals, Chemphyschem, 11, 3996-4001, https://doi.org/10.1002/cphc.201000480, 2010.

Novelli, A., Hens, K., Tatum Ernest, C., Kubistin, D., Regelin, E., Elste, T., Plass-Dülmer, C., Martinez, M., Lelieveld, J., and Harder, H.: Characterisation of an inlet pre-injector laserinduced fluorescence instrument for the measurement of atmospheric hydroxyl radicals, Atmos. Meas. Tech., 7, 3413-3430, https://doi.org/10.5194/amt-7-3413-2014, 2014a.
Novelli, A., Vereecken, L., Lelieveld, J., and Harder, H.: Direct observation of $\mathrm{OH}$ formation from stabilised Criegee intermediates, Phys. Chem. Chem. Phys., 16, 19941-19951, https://doi.org/10.1039/c4cp02719a, 2014b.

Novelli, A., Hens, K., Tatum Ernest, C., Martinez, M., Nölscher, A. C., Sinha, V., Paasonen, P., Petäjä, T., Sipilä, M., Elste, T., PlassDülmer, C., Phillips, G. J., Kubistin, D., Williams, J., Vereecken, L., Lelieveld, J., and Harder, H.: Estimating the atmospheric concentration of Criegee intermediates and their possible interference in a FAGE-LIF instrument, Atmos. Chem. Phys., 17, 78077826, https://doi.org/10.5194/acp-17-7807-2017, 2017.

Novelli, A., Kaminski, M., Rolletter, M., Acir, I.-H., Bohn, B., Dorn, H.-P., Li, X., Lutz, A., Nehr, S., Rohrer, F., Tillmann, R., Wegener, R., Holland, F., Hofzumahaus, A., KiendlerScharr, A., Wahner, A., and Fuchs, H.: Evaluation of $\mathrm{OH}$ and $\mathrm{HO}_{2}$ concentrations and their budgets during photooxidation of 2-methyl-3-butene-2-ol (MBO) in the atmospheric simulation chamber SAPHIR, Atmos. Chem. Phys., 18, 11409-11422, https://doi.org/10.5194/acp-18-11409-2018, 2018.

Paulot, F., Crounse, J. D., Kjaergaard, H. G., Kurten, A., St Clair, J. M., Seinfeld, J. H., and Wennberg, P. O.: Unexpected epoxide formation in the gas-phase photooxidation of isoprene, Science, 325, 730-733, https://doi.org/10.1126/science.1172910, 2009.

Peeters, J. and Muller, J. F.: $\mathrm{HO}(\mathrm{x})$ radical regeneration in isoprene oxidation via peroxy radical isomerisations. II: experimental evidence and global impact, Phys. Chem. Chem. Phys., 12, 1422714235, https://doi.org/10.1039/c0cp00811g, 2010.

Peeters, J., Nguyen, T. L., and Vereecken, L.: $\mathrm{HO}_{x}$ radical regeneration in the oxidation of isoprene, Phys. Chem. Chem. Phys., 11, 5935-5939, https://doi.org/10.1039/b908511d, 2009.

Peeters, J., Muller, J. F., Stavrakou, T., and Nguyen, V. S.: Hydroxyl radical recycling in isoprene oxidation driven by hydrogen bonding and hydrogen tunneling: the upgraded LIM1 mechanism, J. Phys. Chem. A, 118, 8625-8643, https://doi.org/10.1021/jp5033146, 2014.

Praske, E., Crounse, J. D., Bates, K. H., Kurten, T., Kjaergaard, H. G., and Wennberg, P. O.: Atmospheric fate of methyl vinyl ketone: peroxy radical reactions with $\mathrm{NO}$ and $\mathrm{HO}_{2}$, J. Phys. Chem. A, 119, 4562-4572, https://doi.org/10.1021/jp5107058, 2015.

Ren, X. R., Harder, H., Martinez, M., Faloona, I. C., Tan, D., Lesher, R. L., Di Carlo, P., Simpas, J. B., and Brune, W. $\mathrm{H}$.: Interference testing for atmospheric $\mathrm{HO}_{x}$ measurements by laser-induced fluorescence, J. Atmos. Chem., 47, 169-190, https://doi.org/10.1023/B:Joch.0000021037.46866.81, 2004.

Ren, X. R., Olson, J. R., Crawford, J. H., Brune, W. H., Mao, J. Q., Long, R. B., Chen, Z., Chen, G., Avery, M. A., Sachse, G. W., Barrick, J. D., Diskin, G. S., Huey, L. G., Fried, A., Cohen, R. C., Heikes, B., Wennberg, P. O., Singh, H. B., Blake, D. R., and Shetter, R. E.: $\mathrm{HO}_{x}$ chemistry during INTEX-A 2004: Observation, model calculation, and comparison with previous studies, J. Geophys. Res.-Atmos., 113, D05310, https://doi.org/10.1029/2007jd009166, 2008.

Ren, X. R., van Duin, D., Cazorla, M., Chen, S., Mao, J. Q., Zhang, L., Brune, W. H., Flynn, J. H., Grossberg, N., Lefer, B. L., Rappengluck, B., Wong, K. W., Tsai, C., Stutz, J., Dibb, J. E., Jobson, B. T., Luke, W. T., and Kelley, P.: Atmospheric oxidation chemistry and ozone production: Results from SHARP 2009 in Houston, Texas, J. Geophys. Res.-Atmos., 118, 5770-5780, https://doi.org/10.1002/jgrd.50342, 2013. 
Rickly, P. and Stevens, P. S.: Measurements of a potential interference with laser-induced fluorescence measurements of ambient $\mathrm{OH}$ from the ozonolysis of biogenic alkenes, Atmos. Meas. Tech., 11, 1-16, https://doi.org/10.5194/amt-11-1-2018, 2018.

Sander, S. P., Abbatt, J., Barker, J. R., Burkholder, J. B., Friedl, D. M., Golden, D. M., Huie, R. E., Kolb, C. E., Kurylo, M. J., Moortgat, G. K., Orkin, V. L., and Wine, P. H.: Chemical Kinetics and Photochemical Data for Use in Atmospheric Studies, Evaluation No. 17, 2011.

Sheps, L., Scully, A. M., and Au, K.: UV absorption probing of the conformer-dependent reactivity of a Criegee intermediate $\mathrm{CH}_{3} \mathrm{CHOO}$, Phys. Chem. Chem. Phys., 16, 26701-26706, https://doi.org/10.1039/c4cp04408h, 2014.

Shi, Z., Vu, T., Kotthaus, S., Harrison, R. M., Grimmond, S., Yue, S., Zhu, T., Lee, J., Han, Y., Demuzere, M., Dunmore, R. E., Ren, L., Liu, D., Wang, Y., Wild, O., Allan, J., Acton, W. J., Barlow, J., Barratt, B., Beddows, D., Bloss, W. J., Calzolai, G., Carruthers, D., Carslaw, D. C., Chan, Q., Chatzidiakou, L., Chen, Y., Crilley, L., Coe, H., Dai, T., Doherty, R., Duan, F., Fu, P., Ge, B., Ge, M., Guan, D., Hamilton, J. F., He, K., Heal, M., Heard, D., Hewitt, C. N., Hollaway, M., Hu, M., Ji, D., Jiang, X., Jones, R., Kalberer, M., Kelly, F. J., Kramer, L., Langford, B., Lin, C., Lewis, A. C., Li, J., Li, W., Liu, H., Liu, J., Loh, M., Lu, K., Lucarelli, F., Mann, G., McFiggans, G., Miller, M. R., Mills, G., Monk, P., Nemitz, E., O'Connor, F., Ouyang, B., Palmer, P. I., Percival, C., Popoola, O., Reeves, C., Rickard, A. R., Shao, L., Shi, G., Spracklen, D., Stevenson, D., Sun, Y., Sun, Z., Tao, S., Tong, S., Wang, Q., Wang, W., Wang, X., Wang, X., Wang, Z., Wei, L., Whalley, L., Wu, X., Wu, Z., Xie, P., Yang, F., Zhang, Q., Zhang, Y., Zhang, Y., and Zheng, M.: Introduction to the special issue "In-depth study of air pollution sources and processes within Beijing and its surrounding region (APHH-Beijing)", Atmos. Chem. Phys., 19, 7519-7546, https://doi.org/10.5194/acp19-7519-2019, 2019.

Smith, S. C., Lee, J. D., Bloss, W. J., Johnson, G. P., Ingham, T., and Heard, D. E.: Concentrations of $\mathrm{OH}$ and $\mathrm{HO}_{2}$ radicals during NAMBLEX: measurements and steady state analysis, Atmos. Chem. Phys., 6, 1435-1453, https://doi.org/10.5194/acp-6-14352006, 2006.

Stevens, P. S., Mather, J. H., and Brune, W. H.: Measurement of Tropospheric $\mathrm{OH}$ and $\mathrm{HO}_{2}$ by Laser-Induced Fluorescence at Low-Pressure, J. Geophys. Res.-Atmos., 99, 3543-3557, https://doi.org/10.1029/93jd03342, 1994.

Stone, D., Evans, M. J., Edwards, P. M., Commane, R., Ingham, T., Rickard, A. R., Brookes, D. M., Hopkins, J., Leigh, R. J., Lewis, A. C., Monks, P. S., Oram, D., Reeves, C. E., Stewart, D., and Heard, D. E.: Isoprene oxidation mechanisms: measurements and modelling of $\mathrm{OH}$ and $\mathrm{HO}_{2}$ over a South-East Asian tropical rainforest during the OP3 field campaign, Atmos. Chem. Phys., 11, 6749-6771, https://doi.org/10.5194/acp-11-6749-2011, 2011.

Stone, D., Whalley, L. K., Ingham, T., Edwards, P. M., Cryer, D. R., Brumby, C. A., Seakins, P. W., and Heard, D. E.: Measurement of $\mathrm{OH}$ reactivity by laser flash photolysis coupled with laser-induced fluorescence spectroscopy, Atmos. Meas. Tech., 9, 2827-2844, https://doi.org/10.5194/amt-9-2827-2016, 2016.

Taatjes, C. A., Welz, O., Eskola, A. J., Savee, J. D., Scheer, A. M., Shallcross, D. E., Rotavera, B., Lee, E. P., Dyke, J. M., Mok, D. K., Osborn, D. L., and Percival, C. J.: Direct measurements of conformer-dependent reactivity of the Criegee intermediate $\mathrm{CH}_{3} \mathrm{CHOO}$, Science, 340, 177-180, https://doi.org/10.1126/science.1234689, 2013.

Tan, Z., Fuchs, H., Lu, K., Hofzumahaus, A., Bohn, B., Broch, S., Dong, H., Gomm, S., Häseler, R., He, L., Holland, F., Li, X., Liu, Y., Lu, S., Rohrer, F., Shao, M., Wang, B., Wang, M., Wu, Y., Zeng, L., Zhang, Y., Wahner, A., and Zhang, Y.: Radical chemistry at a rural site (Wangdu) in the North China Plain: observation and model calculations of $\mathrm{OH}, \mathrm{HO}_{2}$ and $\mathrm{RO}_{2}$ radicals, Atmos. Chem. Phys., 17, 663-690, https://doi.org/10.5194/acp17-663-2017, 2017.

Tan, Z., Rohrer, F., Lu, K., Ma, X., Bohn, B., Broch, S., Dong, H., Fuchs, H., Gkatzelis, G. I., Hofzumahaus, A., Holland, F., Li, X., Liu, Y., Liu, Y., Novelli, A., Shao, M., Wang, H., Wu, Y., Zeng, L., Hu, M., Kiendler-Scharr, A., Wahner, A., and Zhang, Y.: Wintertime photochemistry in Beijing: observations of $\mathrm{RO}_{x}$ radical concentrations in the North China Plain during the BEST-ONE campaign, Atmos. Chem. Phys., 18, 1239112411, https://doi.org/10.5194/acp-18-12391-2018, 2018.

Tan, Z., Lu, K., Hofzumahaus, A., Fuchs, H., Bohn, B., Holland, F., Liu, Y., Rohrer, F., Shao, M., Sun, K., Wu, Y., Zeng, L., Zhang, Y., Zou, Q., Kiendler-Scharr, A., Wahner, A., and Zhang, Y.: Experimental budgets of $\mathrm{OH}, \mathrm{HO}_{2}$, and $\mathrm{RO}_{2}$ radicals and implications for ozone formation in the Pearl River Delta in China 2014, Atmos. Chem. Phys., 19, 7129-7150, https://doi.org/10.5194/acp-19-7129-2019, 2019.

Teng, A. P., Crounse, J. D., and Wennberg, P. O.: Isoprene Peroxy Radical Dynamics, J. Am. Chem. Soc., 139, 5367-5377, https://doi.org/10.1021/jacs.6b12838, 2017.

Tsiligiannis, E., Hammes, J., Salvador, C. M., Mentel, T. F., and Hallquist, M.: Effect of $\mathrm{NO}_{x}$ on 1,3,5-trimethylbenzene (TMB) oxidation product distribution and particle formation, Atmos. Chem. Phys., 19, 15073-15086, https://doi.org/10.5194/acp-1915073-2019, 2019.

Wang, S., Wu, R., Berndt, T., Ehn, M., and Wang, L.: Formation of Highly Oxidized Radicals and Multifunctional Products from the Atmospheric Oxidation of Alkylbenzenes, Environ. Sci. Technol., 51, 8442-8449, https://doi.org/10.1021/acs.est.7b02374, 2017.

Welz, O., Savee, J. D., Osborn, D. L., Vasu, S. S., Percival, C. J., Shallcross, D. E., and Taatjes, C. A.: Direct kinetic measurements of Criegee intermediate $\left(\mathrm{CH}_{2} \mathrm{OO}\right)$ formed by reaction of $\mathrm{CH}_{2} \mathrm{I}$ with $\mathrm{O}_{2}$, Science, 335, 204-207, https://doi.org/10.1126/science.1213229, 2012.

Welz, O., Eskola, A. J., Sheps, L., Rotavera, B., Savee, J. D., Scheer, A. M., Osborn, D. L., Lowe, D., Murray Booth, A., Xiao, P., Anwar, H. K. M., Percival, C. J., Shallcross, D. E., and Taatjes, C. A.: Rate coefficients of $\mathrm{C}(1)$ and $\mathrm{C}(2)$ Criegee intermediate reactions with formic and acetic Acid near the collision limit: direct kinetics measurements and atmospheric implications, Angew. Chem. Int. Edit., 53, 4547-4550, https://doi.org/10.1002/anie.201400964, 2014.

Whalley, L. K., Furneaux, K. L., Goddard, A., Lee, J. D., Mahajan, A., Oetjen, H., Read, K. A., Kaaden, N., Carpenter, L. J., Lewis, A. C., Plane, J. M. C., Saltzman, E. S., Wiedensohler, A., and Heard, D. E.: The chemistry of $\mathrm{OH}$ and $\mathrm{HO}_{2}$ radicals in the boundary layer over the tropical Atlantic Ocean, Atmos. Chem. Phys., 10, 1555-1576, https://doi.org/10.5194/acp10-1555-2010, 2010. 
Whalley, L. K., Edwards, P. M., Furneaux, K. L., Goddard, A., Ingham, T., Evans, M. J., Stone, D., Hopkins, J. R., Jones, C. E., Karunaharan, A., Lee, J. D., Lewis, A. C., Monks, P. S., Moller, S. J., and Heard, D. E.: Quantifying the magnitude of a missing hydroxyl radical source in a tropical rainforest, Atmos. Chem. Phys., 11, 7223-7233, https://doi.org/10.5194/acp11-7223-2011, 2011.

Whalley, L. K., Blitz, M. A., Desservettaz, M., Seakins, P. W., and Heard, D. E.: Reporting the sensitivity of laser-induced fluorescence instruments used for $\mathrm{HO}_{2}$ detection to an interference from $\mathrm{RO}_{2}$ radicals and introducing a novel approach that enables $\mathrm{HO}_{2}$ and certain $\mathrm{RO}_{2}$ types to be selectively measured, Atmos. Meas. Tech., 6, 3425-3440, https://doi.org/10.5194/amt-6-3425-2013, 2013.

Whalley, L. K., Stone, D., Bandy, B., Dunmore, R., Hamilton, J. F., Hopkins, J., Lee, J. D., Lewis, A. C., and Heard, D. E.: Atmospheric $\mathrm{OH}$ reactivity in central London: observations, model predictions and estimates of in situ ozone production, Atmos. Chem. Phys., 16, 2109-2122, https://doi.org/10.5194/acp16-2109-2016, 2016.

Whalley, L. K., Stone, D., Dunmore, R., Hamilton, J., Hopkins, J. R., Lee, J. D., Lewis, A. C., Williams, P., Kleffmann, J., Laufs, S., Woodward-Massey, R., and Heard, D. E.: Understanding in situ ozone production in the summertime through radical observations and modelling studies during the Clean air for London project (ClearfLo), Atmos. Chem. Phys., 18, 2547-2571, https://doi.org/10.5194/acp-18-2547-2018, 2018.
Winiberg, F. A. F., Smith, S. C., Bejan, I., Brumby, C. A., Ingham, T., Malkin, T. L., Orr, S. C., Heard, D. E., and Seakins, P. W. Pressure-dependent calibration of the $\mathrm{OH}$ and $\mathrm{HO}_{2}$ channels of a FAGE $\mathrm{HO}_{\mathrm{x}}$ instrument using the Highly Instrumented Reactor for Atmospheric Chemistry (HIRAC), Atmos. Meas. Tech., 8, 523-540, https://doi.org/10.5194/amt-8-523-2015, 2015.

Wolfe, G. M., Thornton, J. A., Bouvier-Brown, N. C., Goldstein, A. H., Park, J.-H., McKay, M., Matross, D. M., Mao, J., Brune, W. H., LaFranchi, B. W., Browne, E. C., Min, K.-E., Wooldridge, P. J., Cohen, R. C., Crounse, J. D., Faloona, I. C., Gilman, J. B., Kuster, W. C., de Gouw, J. A., Huisman, A., and Keutsch, F. N.: The Chemistry of Atmosphere-Forest Exchange (CAFE) Model - Part 2: Application to BEARPEX-2007 observations, Atmos. Chem. Phys., 11, 1269-1294, https://doi.org/10.5194/acp-111269-2011, 2011.

Wolfe, G. M., Crounse, J. D., Parrish, J. D., St Clair, J. M., Beaver, M. R., Paulot, F., Yoon, T. P., Wennberg, P. O., and Keutsch, F. N.: Photolysis, $\mathrm{OH}$ reactivity and ozone reactivity of a proxy for isoprene-derived hydroperoxyenals (HPALDs), Phys. Chem. Chem. Phys., 14, 7276-7286, https://doi.org/10.1039/c2cp40388a, 2012. 